\title{
A new primate assemblage from La Verrerie de Roches (Middle Eocene, Switzerland)
}

\author{
Raef Minwer-Barakat ${ }^{a, *}$, Judit Marigó a , Damien Becker ${ }^{\mathrm{b}, \mathrm{c}}$, Loïc Costeur ${ }^{\mathrm{d}}$ \\ a Institut Català de Paleontologia Miquel Crusafont, Universitat Autònoma de Barcelona, 08193 Cerdanyola Del Vallès, Barcelona, Spain \\ b Jurassica Museum, Route de Fontenais 21, 2900 Porrentruy, Switzerland \\ ${ }^{c}$ Department of Geosciences, University of Fribourg, Chemin Du Musée 6, 1700 Fribourg, Switzerland \\ ${ }^{\mathrm{d}}$ Naturhistorisches Museum Basel, Augustinergasse 2, 4001 Basel, Switzerland
}

\begin{abstract}
Primates reached a great abundance and diversity during the Eocene, favored by warm temperatures and by the development of dense forests throughout the Northern Hemisphere. Here we describe new primate material from La Verrerie de Roches, a Middle Eocene karstic infill situated in the Jura Region (Switzerland), consisting of more than 80 dental remains. The primate assemblage from La Verrerie de Roches includes five different taxa. The best represented primate is Necrolemur aff. anadoni, similar in size and overall morphology to Necrolemur anadoni but resembling in some features the younger species Necrolemur antiquus. Microchoerines are also represented by two species of Pseudoloris, P. pyrenaicus and Pseudoloris parvulus, constituting the unique joint record of these two species known up to now. Remains of Adapiformes are limited to one isolated tooth of a large anchomomyin and another tooth belonging to the small adapine Microadapis cf. sciureus. The studied primate association allows assigning La Verrerie de Roches to the Robiacian Land Mammal Age. More specifically, this site can be confidently situated between the MP15 and MP16 reference levels, although the primate assemblage probably indicates some degree of temporal mixing. This is the first record of P. pyrenaicus and a form closely related to $N$. anadoni out of the Iberian Peninsula. The identification of these microchoerines in Switzerland gives further support to the connection of NE Spain and Central Europe during the Middle Eocene.
\end{abstract}

\section{Introduction}

The origin of Euprimates dates back to the beginning of the Eocene, a moment marked by high temperatures and followed by sustained global warmth (Shackelton and Boersma, 1981; Zachos et al., 2001, 2008). During this epoch, the development of dense forests allowed the radiation of primates throughout the Northern Hemisphere. Two main groups of Euprimates became abundant and diverse during the Eocene: the larger-sized adapiforms and the small-bodied omomyiforms (Rose et al., 1994; Covert, 2002; Gebo, 2002; Gunnell and Rose, 2002; Gilbert, 2005; Gingerich, 2012; Godinot, 2015), which are related to the main clades of living primates (strepsirrhines and haplorrhines, respectively).

Abbreviations: BFI, La Bouffie; IPS, Institut de Paleontologia de Sabadell (forme name of the Institut Català de Paleontologia Miquel Crusafont); NMB, Natural History Musem of Basel; SJF, Sant Jaume de Frontanyà; VDR, La Verrerie de Roches.

* Corresponding author.

E-mail address: raef.minwer@icp.cat (R. Minwer-Barakat).
The Robiacian European Land Mammal Age ranges approximately between 43.5 and 37.8 Ma (Vandenberghe et al., 2012). Primates of this age are well known through the abundant and well-preserved material from classical localities such as Egerkingen and Mormont (Switzerland), Creechbarrow (England), Sant Jaume de Frontanyà (Spain) and, especially, from numerous French fossil sites, including Lissieu, Robiac, Grisolles and several levels in the Quercy phosphorites such as Le Bretou and Lavergne (Godinot, 1983, 1985, 2015; Hooker, 1986; Aguilar et al., 1997; Legendre et al., 1997; Hooker and Weidmann, 2000). During the Robiacian, Omomyiformes are represented by the genus Nannopithex and its putative descendant Necrolemur (Minwer-Barakat et al., 2015a), as well as the small-sized and rather diverse genus Pseudoloris. Microchoerus has also been reported from some Robiacian localities, although this genus has recently been suggested to be a paraphyletic group, and the taxonomic allocation of some Middle Eocene forms must be reconsidered (Minwer-Barakat et al., 2017). Regarding the adapiforms, during the Robiacian they are represented in Europe by the anchomomyins Anchomomys cf. quercyi 
from Le Bretou (Godinot, 1988a) and Anchomomys frontanyensis from Sant Jaume de Frontanyà 3 (Marigó et al., 2011), as well as the genus Mazateronodon in Mazaterón (Marigó et al., 2010). Other cercamoniines include the genus Europolemur from Creechbarrow Hill (Hooker, 1986). Adapines are represented by the genera Leptadapis found in Creechbarrow Hill, as well as Adapis from the same site (Hooker, 1986), the latter also recovered from different French (Robiac, Castrais, Grisolles; Louis and Sudre, 1975; Sudre, 1978), Spanish (Mazaterón and Sant Jaume de Frontanyà; Moyà-Solà and Köhler, 1993; Marigó et al., 2014) and Swiss localities (MormontÉclepens; Sudre, 1978).

La Verrerie de Roches, an Eocene site in Switzerland, is rather poorly known despite the fact that is was first mentioned more than a hundred years ago (Stehlin, 1910, 1916). It is a classical network of "siderolithic" fissure fillings like the much better known European reference locality of Egerkingen, also in Switzerland. It is located in the Canton Jura, a few kilometers southeast of the canton's main city, Delémont (Fig. 1). Some material was sampled from karstic fissure fillings at the beginning of the 20th century, leading to an interesting description of some artiodactyl teeth (Stehlin, 1910) and of a single primate fragmentary hemimandible of unknown affinities (Stehlin, 1916). In total about 40 mostly undescribed specimens comprised the historical collection of the Natural History Museum of Basel (NMB). Many karstic fissure fillings within the Late Jurassic basement are known over a rather limited surface, and no reference to what fissure filling was sampled was previously given, so that little information on the precise location of the previously described material can be given. About a hundred years later, new sampling carried out in 2006 in the context of the paleontological investigations along the A16 motorway (Transjurane) led to several hundred kilograms of material being screen washed, ultimately leading to the description of 20 teeth belonging to eight mammalian taxa, all coming from the same karstic fissure filling (Becker et al., 2013). The authors described a rather diverse fauna, which includes rodents (Sciuroides cf. romani, Paradelomys crusafonti, Paradelomys ruetimeyeri, Elfomys cf. tobieni, Elfomys engesseri), a marsupial (Herpetotheriinae indet.), a carnivore (Carnivora indet.), a mixtotherid (Mixtotherium lavergnense), as well as two different primates, assigned to Adapis aff. sudrei and Necrolemur aff. antiquus, each one represented by a single isolated tooth.

Between the historical publications and the recently published work, more excavations were carried out in the 1970s and early 1980s by the NMB. This material was never mentioned in any publication and was stored in the collections of the Museum. It represents the largest collection of teeth from this locality, with more than a thousand specimens representing a large faunal spectrum of mammals and lower vertebrates, making this locality one of the richest for the Middle Eocene of Switzerland and perhaps, once its full potential is assessed, of Europe too. Unfortunately, the precise location of the sampled fissure fillings was not noted on a map of the outcrop and only collection years are available. To date, the outcrop represents a surface of about $50 \mathrm{~m}$ in length over $15 \mathrm{~m}$ in height and at least 36 fissure fillings with reddish sediment are still visible. We know that 10 fossiliferous fissure fillings were sampled back in the 1970s and 1980s; seven others were sampled in 2006 by the new paleontological investigations along the A16 motorway, which could partly, at least, be the same as those of the collection under study here.

In this work we describe in detail the primate specimens from La Verrerie de Roches housed in the collections of the NMB, consisting of more than 80 dental remains. The primate assemblage from La Verrerie de Roches includes five different taxa, three microchoerines and two adapiforms, thus representing one of the most diverse primate associations of the European Middle Eocene.

\section{Material and methods}

The studied material is housed in the collections of the Natural History Museum of Basel. The nomenclature used in the descriptions of the teeth is that described in Minwer-Barakat et al. (2015b). The first and second upper molars of Necrolemur and Pseudoloris, as well as the first and second lower molars of Pseudoloris, have been described together because of the difficulty of distinguishing them when they are found in isolation (they are referred to as $\mathrm{M}^{1-2}$ and $\mathrm{M}_{1-2}$ ). Following Hooker and Harrison (2008), the terms "anterior" and "posterior" are used specifically for the descriptions of the incisors because, whereas the posterior direction equates to distal, the anterior does not equate with mesial. Measurements have been taken using an optic caliper "Nikon measuroscope 10" connected to a monitor "Nikon SC112", as defined by Godinot (2003). Micrographs were taken using the Environmental Scanning Electron Microscope (ESEM) of the Universitat de Barcelona.

\section{Systematic paleontology}

Order PRIMATES Linnaeus, 1758

Suborder HAPLORHINI Pocock, 1918

Infraorder OMOMYIFORMES Schmid, 1982
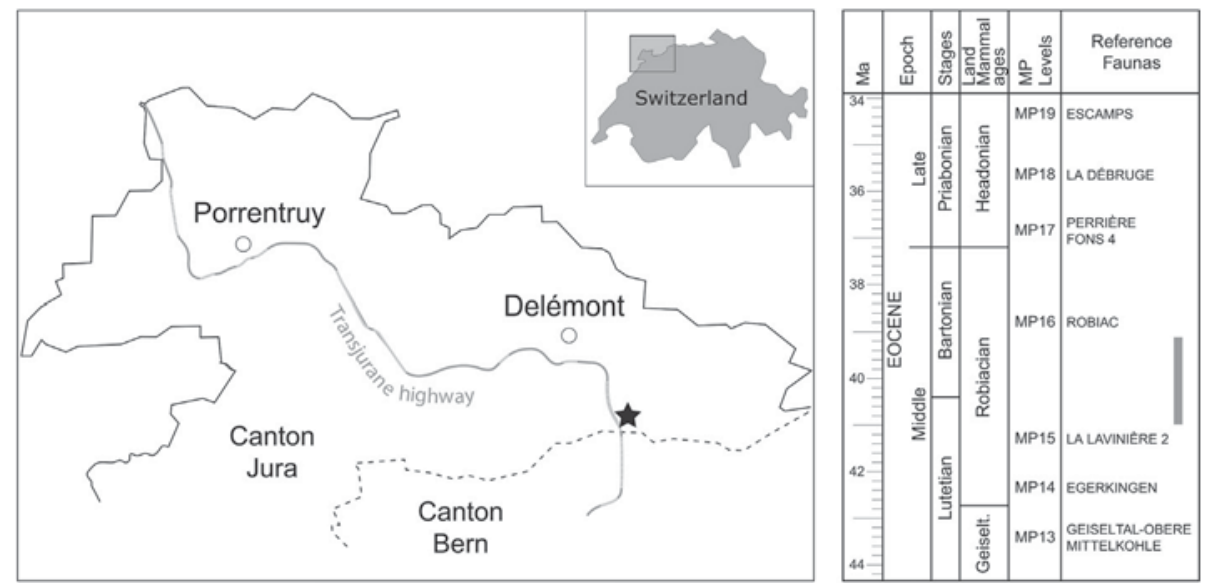

Figure 1. Location map and biochronological position of the site of La Verrerie de Roches (courtesy Becker et al., 2013). Location on map is indicated by the black star. The gray bar indicates uncertainty of the age within the late Lutetian and Bartonian stages, or Robiacian Land Mammal Age. 
Family OMOMYIDAE Trouessart, 1879.

Subfamily MICROCHOERINAE Lydekker, 1887

Genus NECROLEMUR Filhol, 1873

Necrolemur aff. anadoni Minwer-Barakat, Marigó and Moyà-Solà, 2015a

Figures 2-4

\subsection{Description}

$\mathbf{C}_{\mathbf{1}}$ : The buccal face is convex, whereas the lingual side is concave. The base of the crown rises on the mesial part of the tooth, and descends further on the lingual part than on the buccal side, so the crown is markedly asymmetrical. Two sharp cristids descend from the apex and reach the base of the crown, the mesial one being shorter than the distal. The lingual cingulid is strong and continuous. A buccal cingulid is barely marked.

$\mathbf{P}_{4}$ : The protoconid is acute. The paracristid descends mesially from the protoconid, reaches the base of the crown and curves lingually, continuing in a well-developed buccal cingulid. There is no paraconid. The protocristid is curved and connects the protoconid to a high, tubercular metaconid. There is a thin longitudinal cristid crossing the distal slope of the trigonid, from the protocristid to the distal cingulid. Another weaker and shorter cristid runs distally from the protoconid, without reaching the crown base. The distal cingulid is well marked and rises notably at the middle part of the distal side, forming a triangular facet. The buccal cingulid is weak.

$\mathbf{M}_{\mathbf{1}}$ : The trigonid is markedly narrower than the talonid. The paraconid is large, tubercular and lower than the protoconid and metaconid; it is connected to the protoconid by a curved paracristid, and separated from the metaconid by a deep notch. The protocristid shows a constriction at the middle of its length. There are three thick and poorly defined cristids running from the paraconid, metaconid and protoconid towards the center of the trigonid basin. The cristid obliqua ends at the level of the constriction of the protocristid. There is no mesoconid. The postcristid has a protrusion, placed closer to the hypoconid than to the entoconid, but there is not a distinct hypoconulid. The mesial end of the preentocristid is curved buccally and does not connect to the postmetacristid, so the talonid basin is open lingually by a notch. In most specimens, the enamel wrinkling is hardly marked on the talonid basin, and is only expressed by two weak ridges starting at the entoconid and hypoconid (specimen NMB V.R. 2 displays a more complex crenulation, Fig. 2K). The buccal cingulid is strong and occupies the mesial, buccal and distal borders of the tooth.

$\mathbf{M}_{\mathbf{2}}$ : The trigonid is notably shorter than in the $\mathbf{M}_{1}$. The protoconid is placed in a more lingual position than the hypoconid, so the trigonid is clearly narrower than the talonid. The paraconid is attached to the metaconid, hardly differentiated from this latter cusp. The paracristid connects the protoconid to the paraconid-metaconid complex, closing the trigonid basin. There is a thick cristid running buccally from the metaconid and a small lingual spur on the protoconid, but they do not join each other. The protocristid is slightly constricted at the middle of its length. The cristid obliqua runs mesiolingually from the hypoconid and, close to its mesial end, turns buccally and connects to the trigonid wall at the level of the protoconid. There is no mesoconid. The entoconid is lower than the hypoconid. The postcristid has a small protuberance that does not constitute a distinct hypoconulid. The pre-entocristid is strongly curved buccally and separated from the postmetacristid by a deep notch, so the talonid basin is open lingually. The enamel wrinkling on the talonid is only expressed by one or two weak cristids descending mesiobuccally from the entoconid, and another cristid running mesiolingually from the hypoconid, none of which reach the center of the basin. The buccal cingulid is as in the $M_{1}$.
$\mathbf{M}_{3}$ : The trigonid is wider than in the $\mathbf{M}_{2}$ : the protoconid is in a slightly more lingual position than the hypoconid, but the difference is not so accentuated as in the other lower molars. The paraconid is fused with or hardly differentiated from the metaconid in six out of seven specimens, but it is a distinct cusp in NMB V.R.62 (Fig. 2AA). The paracristid connects the protoconid to the paraconid (or to the paraconid-metaconid complex), closing the trigonid basin completely. There is a cristid running buccally from the paraconid, which occupies less than a half of the trigonid width. The protocristid is continuous. The cristid obliqua is V-shaped, with a distal part running mesiolingually from the hypoconid and a mesial part directed mesiobuccally and connected to the base of the protoconid. There is no mesoconid. The entoconid is lower than the hypoconid and situated in a somewhat more distal position. The pre-entocristid is curved buccally and separated from the postmetacristid by a deep and wide valley that opens the talonid basin lingually. The hypoconulid lobe is wide and shows two distinct cusps. This lobe is better differentiated from the talonid basin on the buccal part than on the lingual part, meaning that the concavity separating the hypoconulid from the hypoconid is more marked than that separating the hypoconulid from the entoconid. The enamel wrinkling is more accentuated than in the $\mathrm{M}_{1}$ and $\mathrm{M}_{2}$, with several sinuous ridges descending from the main cusps towards the center of the talonid. The buccal cingulid occupies the mesial and buccal sides; it is weak at the base of the hypoconid and ends at the buccal base of the hypoconulid lobe.

$\mathbf{I}^{\mathbf{1}}$ : The crown is high and markedly compressed buccolingually. The apex is acute. The buccal side is slightly convex and the lingual side is concave. There is a long crista running on the posterior margin, separating the buccal and lingual sides. At the posterior base of the crown, there is a distinct talon, especially prominent in specimen NMB V.R.65 (Fig. 3C). A well-marked cingulum borders the lingual side of the tooth, starting close to the apex and reaching the talon.

$\mathbf{C}^{\mathbf{1}}$ : The crown is high and much longer than wide. The base of the crown rises markedly on the mesial part of the tooth. The buccal side is convex, the lingual side is concave and in some specimens shows a distolingual expansion (especially marked in specimen NMB V.R.85; Fig. 3G). From the apex, which is shifted mesially, three cristae descend. The cristae running mesially (anterocrista) and mesiolingually are short but well marked. They form an acute angle and delimit a triangular basin on the mesiolingual part of the tooth. The crista descending distally from the apex (posterocrista) is weaker than the other two. The lingual cingulum, strong and high, occupies the lingual and distal borders. A weaker buccal cingulum is observable in only three out of five specimens.

$\mathbf{P}^{2}$ : The outline is oval, somewhat longer than wide. The single cusp is pointed, with the apex placed mesially. The buccal side is convex, the lingual one is concave, in some specimens slightly expanded distolingually. Three sharp cristae descend from the apex. The posterocrista does not reach the base of the crown. The anterocrista and the mesiolingual crista delimit a deep triangular mesiolingual basin. The cingulum is strong along the mesial, lingual and distal borders of the tooth, and becomes weaker on the buccal side, even interrupted in one specimen.

$\mathbf{P}^{\mathbf{3}}$ : The outline is subtriangular, with the buccal border longer than the lingual one, so the mesial and distal borders tend to converge lingually. The paracone is high and pointed and, as in the $\mathrm{P}^{2}$, shows three cristae descending from its apex. The anterocrista is straight and reaches the base of the crown. The anterocrista and the crista running mesiolingually from the paracone enclose a triangular basin in mesiolingual position. The precingulum rises slightly at its connection with the anterocrista, but there is not a distinct parastyle. The posterocrista descends distally from the paracone and, close to the base of the tooth, it curves buccally and thickens 
A
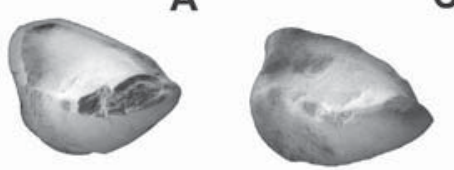

C

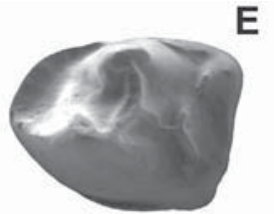

D
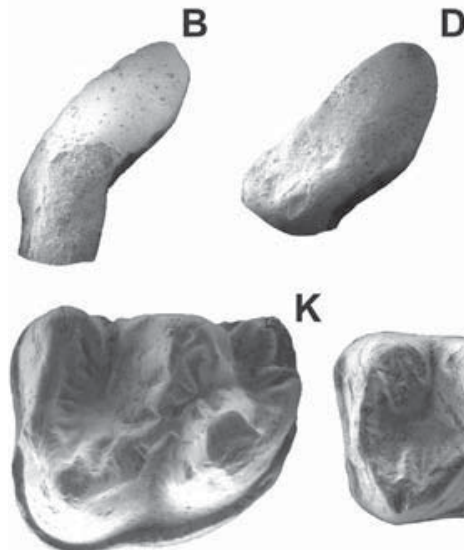

K

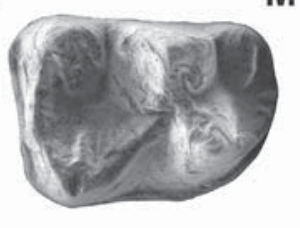

M

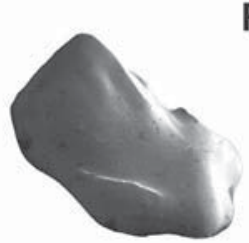

F

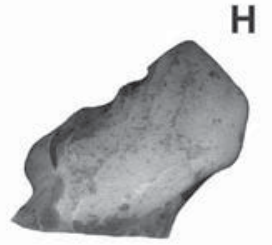

H

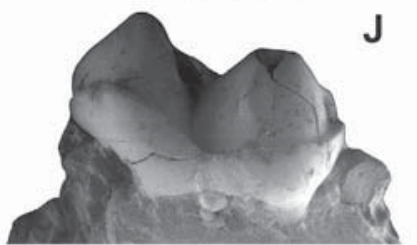

0

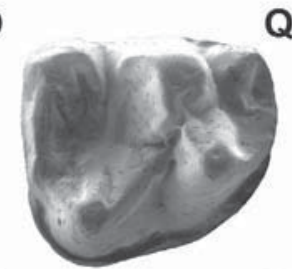

Q
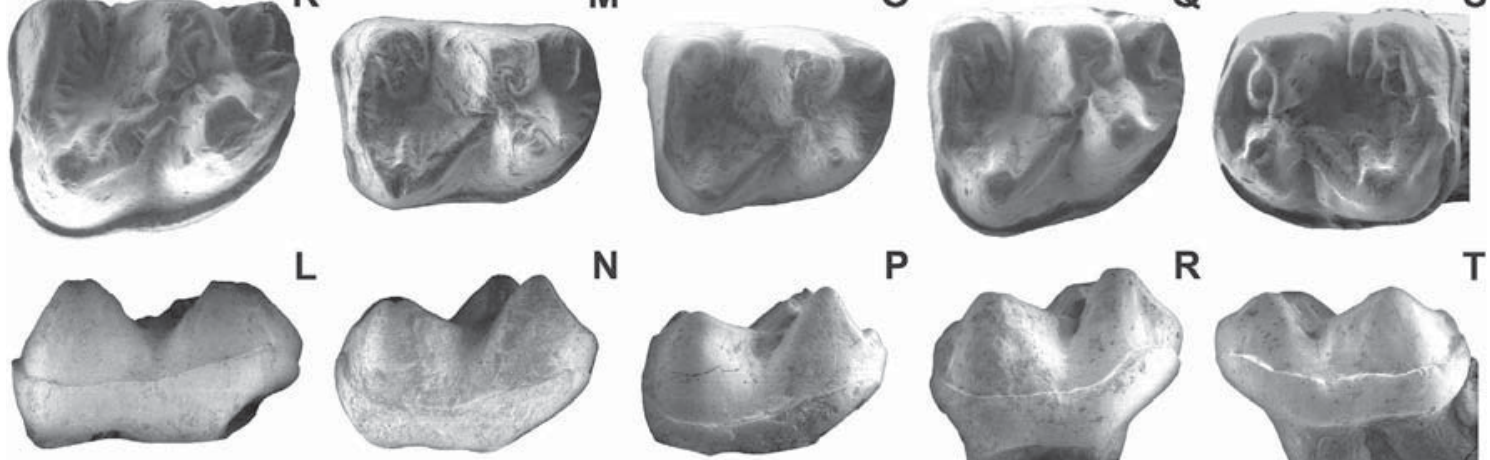

N
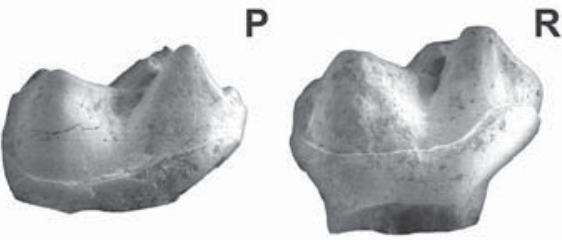

R

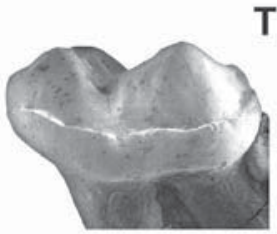

U

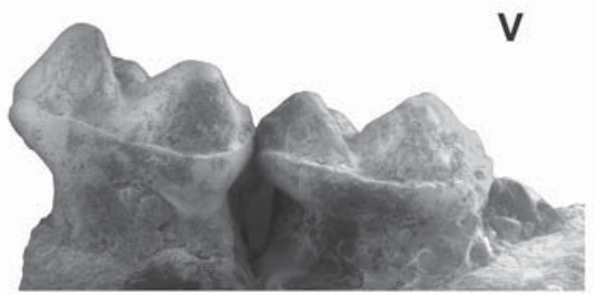

W

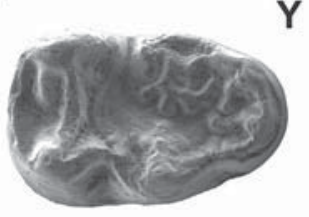

$Y$

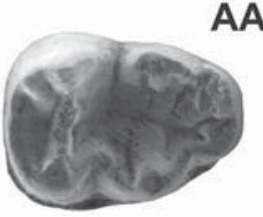

X

Z

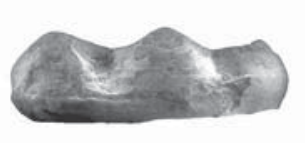

AA

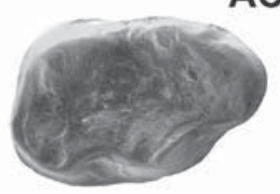

AC

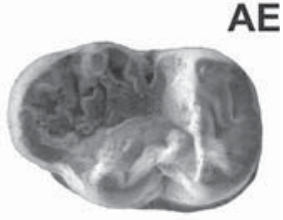

AB
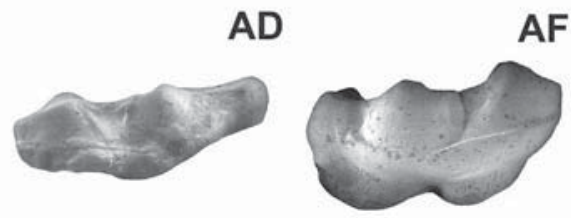

S
1

Figure 2. ESEM images of the lower teeth of Necrolemur aff. anadoni Minwer-Barakat et al., 2015a from La Verrerie de Roches. A-B: right $C_{1}$ (NMB V.R.64) in occlusal (A) and buccal (B) views; C-D: right $C_{1}$ (NMB V.R.110) in occlusal (C) and buccal (D) views; E-F: left $P_{4}$ (NMB V.R.73) in occlusal (E) and buccal (F) views; G-H: right $P_{4}$ (NMB V.R.42) in occlusal (G) and buccal (H) views; I-J: left $\mathrm{M}_{1}$ (NMB V.R.1) in occlusal (I) and buccal (J) views; $K-$ L: right $\mathrm{M}_{1}$ (NMB V.R.2) in occlusal (K) and buccal (L) views; M-N: right $\mathrm{M}_{1}$ (NMB V.R.53) in occlusal (M) and buccal (N) views; O-P: right $\mathrm{M}_{1}$ (NMB V.R.78) in occlusal (O) and buccal (P) views; Q-R: right $\mathrm{M}_{1}$ (NMB V.R.79) in occlusal (Q) and buccal (R) views; $\mathrm{S}-\mathrm{T}$ : left $\mathrm{M}_{2}$ (NMB V.R.80) in occlusal (S) and buccal (T) views; U-V: left mandible fragment with $\mathrm{M}_{1}-\mathrm{M}_{2}$ (NMB V.R.61) in occlusal (U) and buccal (V) views; W-X: left M 3 (NMB V.R.55) in occlusal (W) and buccal (X) views; Y-Z: left $M_{3}$ (NMB V.R.82) in occlusal (Y) and buccal (Z) views; AA-AB: left M $M_{3}(N M B$ V.R.62) in occlusal (AA) and buccal (AB) views; AC-AD: left $\mathrm{M}_{3}$ (NMB V.R.83) in occlusal (AC) and buccal (AD) views; AE-AF: right $\mathrm{M}_{3}$ (NMB V.R.56) in occlusal (AE) and buccal (AF) views. Scale bar represents 1 mm.

forming a metastyle (in specimen NMB V.R.58 the metastyle is not observable, but it may be due to the poor preservation of the enamel). The lingual lobe is reduced and has a small but welldifferentiated protocone in the mesiolingual position. The precingulum and the postcingulum, bordering the mesial and distal borders respectively, are strong and both connect to the protocone. There is also a buccal cingulum, weaker than the other cingula.

$\mathbf{P}^{\mathbf{4}}$ : These premolars are markedly wider than long. The buccal border is longer than the lingual one, but this difference is less accentuated than in the $\mathrm{P}^{3}$. The paracone is high and acute. The 

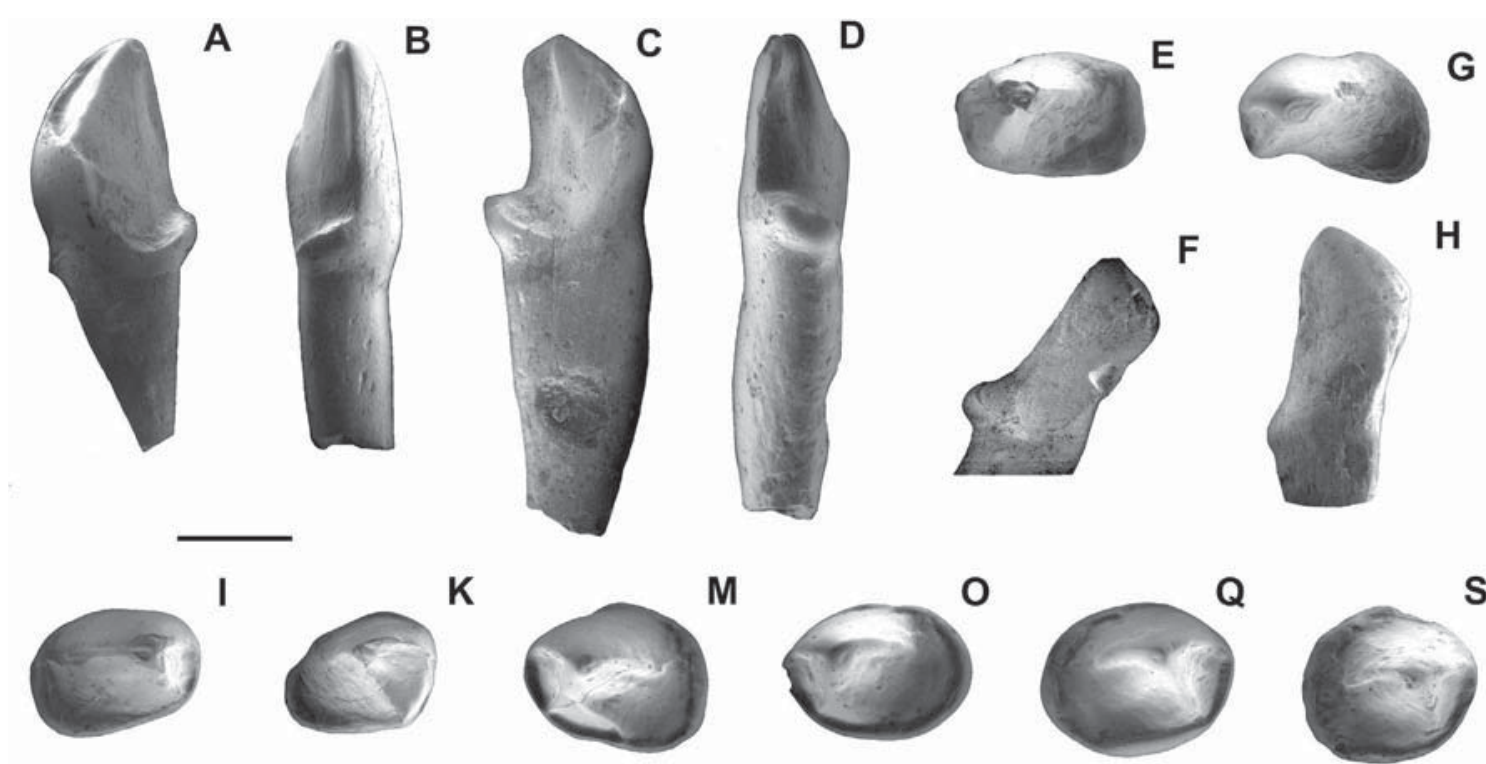
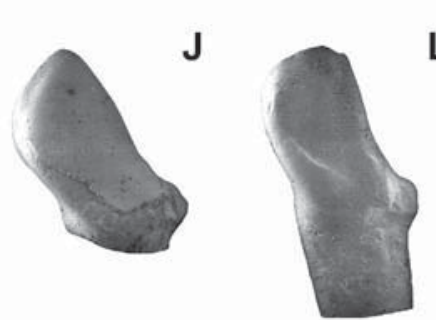

L

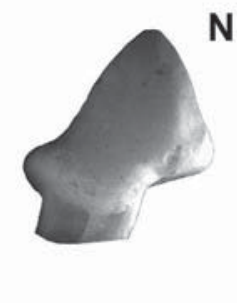

U
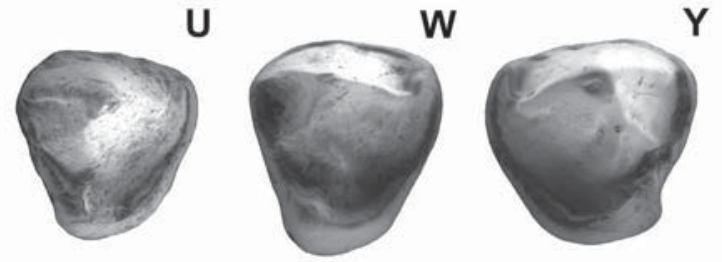

v

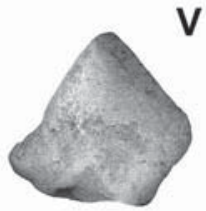

Z
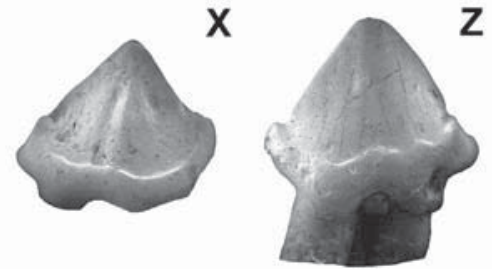
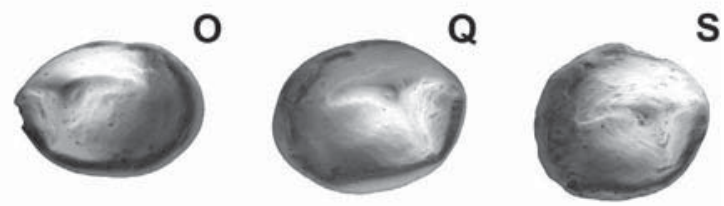

N

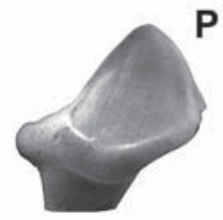

$\mathbf{R}$
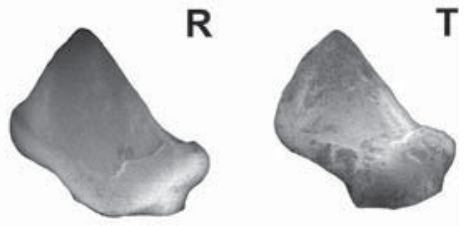

\section{T}

S
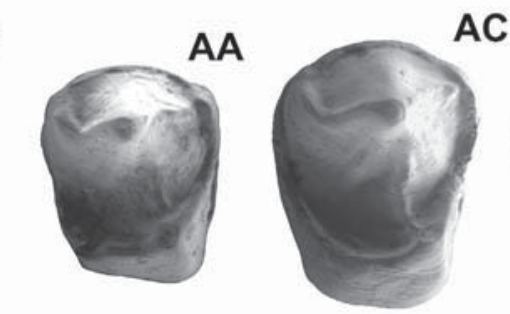

AC
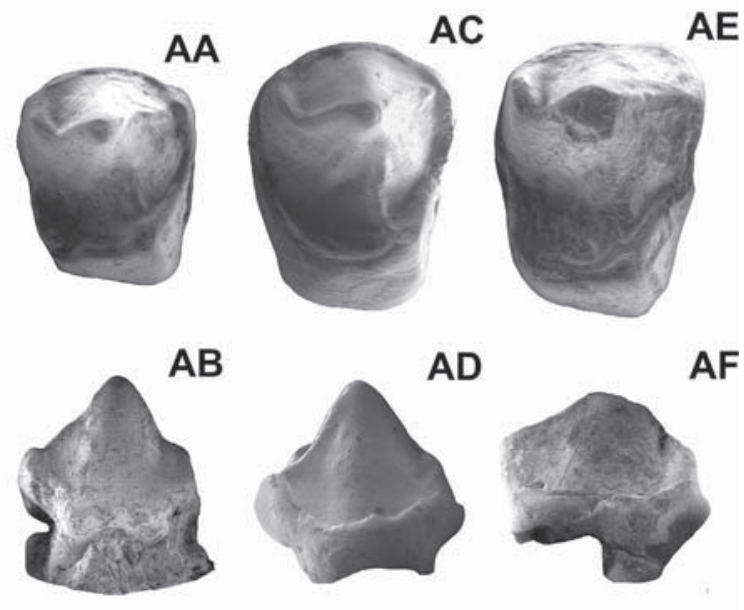

AD

AF

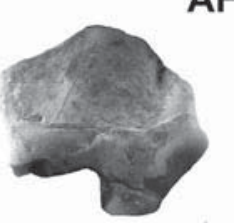

Figure 3. ESEM images of the upper incisors, canines and premolars of Necrolemur aff. anadoni Minwer-Barakat et al., 2015a from La Verrerie de Roches. A-B: left $I^{1}$ (NMB V.R.84) in mesial (A) and posterior (B) views; C-D: right $\mathrm{I}^{1}$ (NMB V.R.65) in mesial (C) and posterior (D) views; E-F: left $\mathrm{C}^{1}$ (NMB V.R.43) in occlusal (E) and buccal (F) views; G-H: left C ${ }^{1}$ (NMB V.R.85) in occlusal (G) and buccal (H) views; I-J: right $C^{1}$ (NMB V.R.66) in occlusal (I) and buccal (J) views; K-L: right $C^{1}$ (NMB V.R.103) in occlusal (K) and buccal (L) views; $\mathrm{M}-\mathrm{N}$ : left $\mathrm{P}^{2}$ (NMB V.R.50) in occlusal (M) and buccal (N) views; O-P: left $\mathrm{P}^{2}$ (NMB V.R.86) in occlusal (O) and buccal (P) views; Q-R: right $\mathrm{P}^{2}$ (NMB V.R.51) in occlusal (Q) and buccal (R) views; $S-T$ : right $\mathrm{P}^{2}$ (NMB V.R.87) in occlusal (S) and buccal (T) views; U-V: left $\mathrm{P}^{3}$ (NMB V.R.58) in occlusal (U) and buccal (V) views; W-X: left $\mathrm{P}^{3}$ (NMB V.R.88) in occlusal (W) and buccal $(X)$ views; $Y-Z$ : right $\mathrm{P}^{3}$ (NMB V.R.89) in occlusal (Y) and buccal (Z) views; $A A-A B$ : right $\mathrm{P}^{4}$ (NMB V.R.44) in occlusal (AA) and buccal (AB) views; $A C-A D$ : right $\mathrm{P}^{4}$ (NMB V.R.69) in occlusal (AC) and buccal (AD) views; $A E-A F$ : right $\mathrm{P}^{4}$ (NMB V.R.90) in occlusal (AE) and buccal (AF) views. Scale bar represents 1 mm.

anterocrista is straight and ends in a distinct parastyle. The posterocrista curves markedly towards the distobuccal corner of the tooth and ends in an inflated metastyle, more developed than the parastyle. Contrary to the $\mathrm{P}^{2}$ and the $\mathrm{P}^{3}$, there is no sharp mesiolingual crista delimiting a mesiolingual basin. Instead, there is a more or less marked lingual crista descending from the paracone towards the protocone. In some specimens, the enamel is wrinkled on the lingual slope of the paracone, displaying some other cristae. The lingual lobe is broader than in the $\mathrm{P}^{3}$ and has a well-developed protocone in mesiolingual position. The precingulum connects the parastyle to the protocone. The postcingulum starts at the protocone, borders the lingual and distal borders, and ends at the level of the metastyle. The buccal cingulum is weaker than the precingulum and postcingulum.

$\mathbf{M}^{\mathbf{1 - 2}}$ : First and second upper molars have been described together due to their strong similarity in size and morphology, which makes distinguishing isolated specimens very difficult. The outline is rectangular, wider than long. The paracone is slightly larger than the metacone. The preparacrista is short and straight, and thickens at its mesial end forming a very small parastyle. 

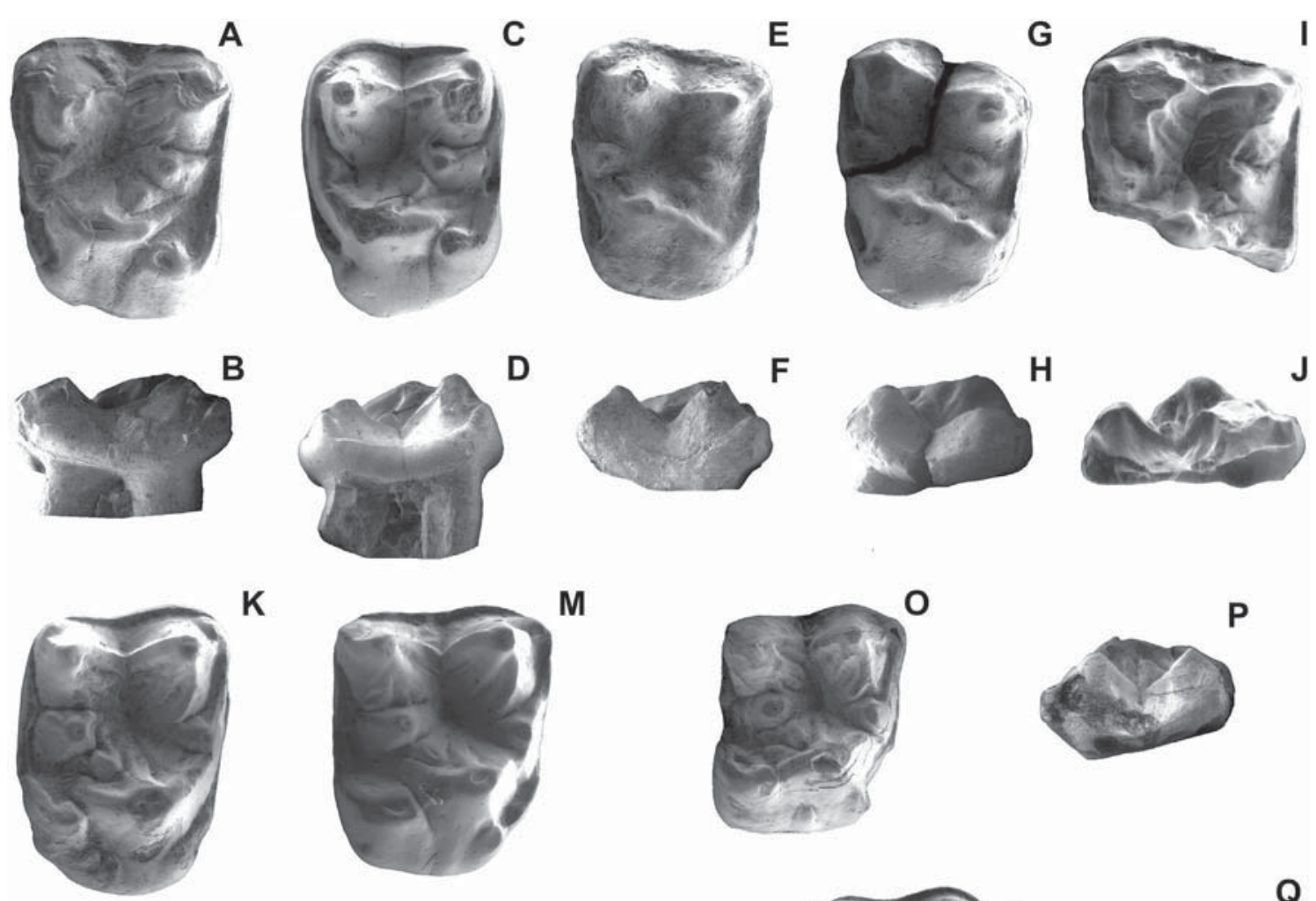

M
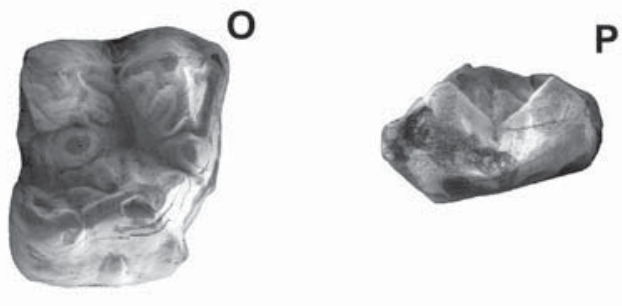

$\mathbf{L}$
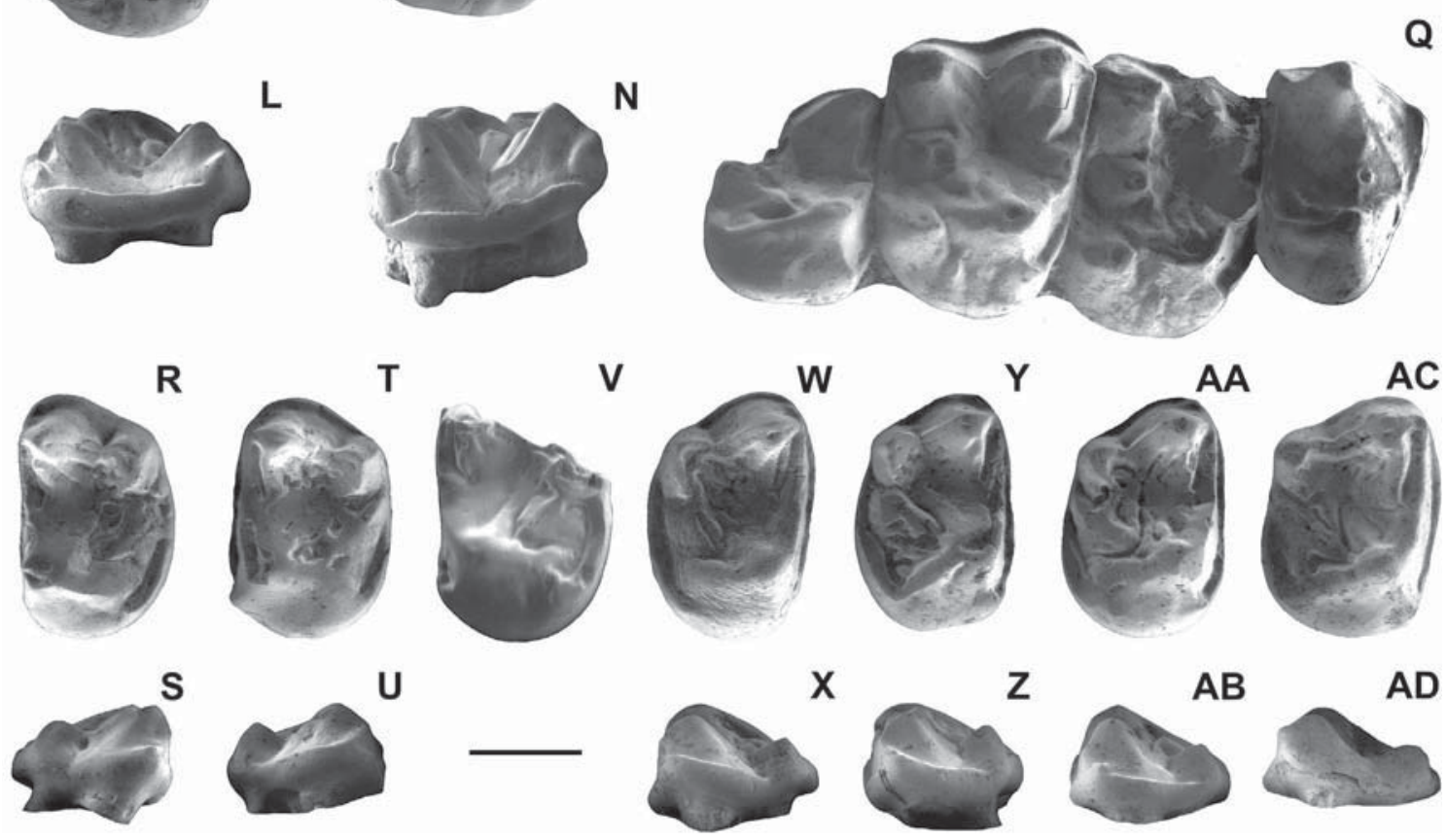

Figure 4. ESEM images of the upper premolars and molars of Necrolemur aff. anadoni Minwer-Barakat et al., 2015a from La Verrerie de Roches. A-B: left ${ }^{1-2}$ (NMB V.R.60) in occlusal (A) and buccal (B) views; C-D: left $\mathrm{M}^{1-2}$ (NMB V.R.91) in occlusal (C) and buccal (D) views; $\mathrm{E}-\mathrm{F}$ : left $\mathrm{M}^{1-2}$ (NMB V.R.46) in occlusal (E) and buccal (F) views; G-H: left $\mathrm{M}^{1-2}$ (NMB V.R.47) in occlusal (G) and buccal (H) views; I-J: left $\mathrm{M}^{1-2}$ (NMB V.R.92) in occlusal (I) and buccal (J) views; K-L: right $\mathrm{M}^{1-2}$ (NMB V.R.95) in occlusal (K) and buccal (L) views;

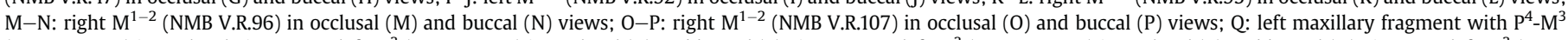
(NMB V.R.102) in occlusal view; R-S: left $\mathrm{M}^{3}$ (NMB V.R.98) in occlusal (R) and buccal (S) views; T-U: left $\mathrm{M}^{3}$ (NMB V.R.108) in occlusal (T) and buccal (U) views; V: left $\mathrm{M}^{3}$ (NMB V.R.109) in occlusal view; $\mathrm{W}-\mathrm{X}$ : right $\mathrm{M}^{3}$ (NMB V.R.99) in occlusal (W) and buccal (X) views; $\mathrm{Y}-\mathrm{Z}$ : right $\mathrm{M}^{3}$ (NMB V.R.100) in occlusal (Y) and buccal (Z) views; $A$ A-AB: right $\mathrm{M}^{3}$ (NMB V.R.101) in occlusal (AA) and buccal (AB) views; $A C-A D$ : right $\mathrm{M}^{3}$ (NMB V.R.59) in occlusal (AC), and buccal (AD) views. Scale bar represents 1 mm.

Postparacrista and premetacrista are connected, forming a nearly straight centrocrista. The postmetacrista runs distobuccally from the metacone and thickens, forming a distinct metastyle, which is larger than the parastyle. There is no trace of a mesostyle. The paraconule, large and tubercular, is connected to the parastyle by the preparaconule crista and, except for specimen NMB V.R.107
(Fig. 40), it is also connected to the protocone by a preprotocrista. There is a hypoparacrista running lingually from the paracone, which only reaches the paraconule in one specimen (NMB V.R.92, Fig. 4I). All the available specimens show two distinct metaconules. The buccal metaconule is a tubercular, voluminous cusp, similar in size or slightly larger than the paraconule. It can be either separated 
from the metacone by a valley (e.g., NMB V.R.47 and 96, Fig. 4G and $\mathrm{M})$ or connected to the metacone by a premetaconule crista (e.g., NMB V.R.91 and 92, Fig. 4C and I). The lingual metaconule varies from a more or less inflated crest (observable in six out of 13 specimens preserving the distal part) to a rounded tubercular cusp (present in seven teeth). From the protocone, a thick postprotocrista runs distally, which only connects to the hypocone in four out of 12 specimens preserving the distolingual region (e.g., NMB V.R.46 and 47, Fig. 4E and G). In the other eight specimens, the postprotocrista lays between the hypocone and the lingual metaconule, without connecting with any of these cusps. In four of these latter specimens, the hypocone is connected to the protocone by means of a very weak postprotocingulum (e.g., NMB V.R.60 and 95, Fig. $4 \mathrm{~A}$ and $\mathrm{K}$ ), while in the remaining four, the hypocone is completely isolated from the protocone (e.g., NMB V.R.91 and 96, Fig. 4C and $\mathrm{M}$ ). The hypocone is large, tubercular and placed in a distolingual position with respect to the protocone. The posthypocrista continues in a postcingulum that borders the entire distal side of the tooth, enclosing a small talon basin. The ectocingulum is strong and occupies the buccal border, from the parastyle to the metastyle. The precingulum is much weaker than the postcingulum and ectocingulum, and in most specimens it is connected to a more or less developed bulge placed at the mesiolingual base of the protocone. The enamel crenulation, not much accentuated, is mainly expressed by some thick ridges descending from the paracone, metacone and protocone, which do not reach the center of the trigon basin.

$\mathbf{M}^{\mathbf{3}}$ : The outline is wider than long. The mesial border is straight and the buccal, distal and lingual borders are convex. The paracone is notably larger than the metacone. The preparaconule crista rises at its junction with the preparacrista, but there is not a distinct parastyle. There is no trace of postmetacrista or mestastyle. A small paraconule is only observable in four out of eight specimens preserving the mesial part. The metaconules are variable. Some specimens have a relatively large tubercular buccal metaconule and a smaller and crest-shaped lingual metaconule (e.g., NMB V.R.100, Fig. 4Y). Other teeth display an inflated crista, without any distinct conule (e.g., NMB V.R.109, Fig. 4V). The protocone is relatively high. The preprotocrista is straight and directed buccally. The postprotocrista is thick and directed distally, without a connection to the metaconule. There is no hypocone. The talon basin is very reduced or indistinct. Precingulum and postcingulum are well marked and occupy the entire mesial and distal borders, respectively. There is no lingual cingulum. The ectocingulum is strong on the base of the paracone, and thinner or even interrupted on the base of the metacone. The enamel wrinkling on the trigon basin is moderate, with some specimens showing several ridges descending from the paracone, metacone and protocone. One specimen
(NMB V.R.100, Fig. 4Y) shows some crenulation on its incipient talon basin, between the metaconules and the postcingulum.

\subsection{Measurements}

See Table 1.

\subsection{Comparisons}

The size of the teeth of Necrolemur aff. anadoni from La Verrerie de Roches is, in general terms, similar to that of Necrolemur anadoni from Sant Jaume de Frontanyà- 1 , although the range of variation is wider in VDR due to the larger sample size (Fig. 5). The only significant difference is found in two $\mathrm{M}_{1}$ from VDR that are notably larger than the rest and overlap the size range of the species $\mathrm{Nec}$ rolemur antiquus. Morphologically, the $\mathrm{P}_{4}$ and $\mathrm{M}_{1}$ are very similar in $N$. anadoni from SJF and $N$. aff. anadoni from VDR. In the $\mathrm{M}_{2}$ and $\mathrm{M}_{3}$ from VDR, the protoconid is in a slightly more buccal position than in those from SJF, so the trigonid is somewhat wider (Fig. 6A, F, G). In addition, the paraconid is slightly better differentiated from the metaconid in the $\mathrm{M}_{2}$ and $\mathrm{M}_{3}$ of $N$. anadoni from SJF, whereas in the sample from VDR these two cusps are generally fused, being distinguishable from each other in only a few specimens (e.g., NMB V.R.62, Fig. 2AA). The hypoconulid lobe is a little longer in the $\mathrm{M}_{3}$ of $N$. aff. anadoni from VDR than in N. anadoni. Regarding the upper teeth, the crown is slightly higher in the $\mathrm{I}^{1}$ from VDR than in the single tooth from SJF. No relevant morphological difference is observed in the upper premolars from the two samples. The $\mathrm{M}^{1-2}$ of $N$. aff. anadoni from VDR mainly differ from those of $N$. anadoni from its type locality in the more developed conules: the paraconule and buccal metaconule are, in general terms, larger in the specimens from VDR. The lingual metaconule, crestiform in the three available molars from SJF-1, is tubercular in half of the $\mathrm{M}^{1-2}$ from VDR and crestiform in the other half. Other characters, however, are identical in the two samples. For instance, the postprotocrista connects to the hypocone in one of the three specimens from SJF (Fig. 6B-D) and in a third of the available specimens from VDR, lying between the hypocone and the lingual metaconule in the rest. The enamel wrinkling also has a very similar development in the two samples. Some characters, such as whether the paraconule is connected to the paracone or disconnected from the protocone, are seen in very few specimens from VDR; their absence in the SJF may be due to the smaller sample size. The $\mathrm{M}^{3}$ from VDR are, in general terms, very similar to the single specimen from SJF. Some teeth from VDR lack the small paraconule present in the specimen from SJF-1, or have a less developed buccal metaconule. Other $\mathrm{M}^{3}$ from VDR are more expanded distolingually than the single specimen from SJF-1, showing an incipient talon basin.

\section{Table 1}

Measurements (in mm) of the teeth of Necrolemur aff. anadoni Minwer-Barakat et al., 2015a from La Verrerie de Roches. L': length perpendicular to the root axis; H': height parallel to the root axis.

\begin{tabular}{|c|c|c|c|c|c|c|c|c|c|c|c|c|c|c|c|c|c|c|c|c|}
\hline \multirow[t]{2}{*}{ Tooth } & \multicolumn{4}{|c|}{ Length } & \multicolumn{4}{|c|}{ Width } & \multicolumn{4}{|c|}{ Height } & \multicolumn{4}{|c|}{$\mathrm{L}^{\prime}$} & \multicolumn{4}{|c|}{$\mathrm{H}^{\prime}$} \\
\hline & $n$ & Min & Mean & Max & $n$ & Min & Mean & Max & $n$ & Min & Mean & Max & $n$ & Min & Mean & Max & $n$ & Min & Mean & Max \\
\hline$C_{1}$ & 3 & 2.05 & 2.12 & 2.19 & 3 & 1.22 & 1.25 & 1.30 & 2 & 0.89 & 1.00 & 1.11 & 3 & 1.37 & 1.42 & 1.47 & & & & \\
\hline $\mathrm{P}_{4}$ & 3 & 2.06 & 2.10 & 2.15 & 2 & 1.65 & 1.675 & 1.70 & 2 & 1.26 & 1.295 & 1.33 & & & & & & & & \\
\hline$M_{1}$ & 8 & 2.25 & 2.41 & 2.64 & 8 & 1.75 & 1.95 & 2.25 & & & & & & & & & & & & \\
\hline $\mathrm{M}_{2}$ & 2 & 2.15 & 2.17 & 2.19 & 2 & 1.89 & 1.94 & 1.99 & & & & & & & & & & & & \\
\hline $\mathrm{M}_{3}$ & 6 & 2.16 & 2.32 & 2.51 & 6 & 1.49 & 1.60 & 1.65 & & & & & & & & & & & & \\
\hline $\mathrm{I}^{1}$ & 2 & 1.79 & 1.84 & 1.89 & 2 & 1.03 & 1.06 & 1.09 & 2 & 1.45 & 1.485 & 1.52 & & & & & & & & \\
\hline$C^{1}$ & 5 & 1.90 & 1.98 & 2.08 & 5 & 1.14 & 1.20 & 1.26 & 5 & 0.98 & 1.08 & 1.16 & 5 & 1.22 & 1.43 & 1.55 & 5 & 1.76 & 1.85 & 1.89 \\
\hline $\mathrm{P}^{2}$ & 5 & 1.58 & 1.70 & 1.80 & 5 & 1.27 & 1.36 & 1.47 & & & & & & & & & & & & \\
\hline $\mathrm{P}^{3}$ & 3 & 1.64 & 1.79 & 1.93 & 3 & 1.72 & 1.88 & 2.02 & & & & & & & & & & & & \\
\hline $\mathrm{P}^{4}$ & 7 & 1.65 & 1.87 & 2.15 & 6 & 2.05 & 2.35 & 2.53 & & & & & & & & & & & & \\
\hline $\mathrm{M}^{1-2}$ & 8 & 1.87 & 2.065 & 2.28 & 8 & 2.42 & 2.76 & 3.00 & & & & & & & & & & & & \\
\hline $\mathrm{M}^{3}$ & 6 & 1.45 & 1.525 & 1.62 & 6 & 2.18 & 2.23 & 2.28 & & & & & & & & & & & & \\
\hline
\end{tabular}


The teeth of $N$. aff. anadoni from VDR are clearly smaller than those of N. antiquus from Le Bretou, Lavergne and La Bouffie (Fig. 5). Morphological differences are also notable, as is evident from a comparison with the abundant sample of $N$. antiquus from La Bouffie. The $\mathrm{P}_{4}$ of $N$. antiquus has a lower metaconid than that of $N$. aff. anadoni from VDR, a better developed longitudinal cristid and, in some specimens, additional cristids on the distal slope of the trigonid. The enamel wrinkling is much more marked in the lower molars of $N$. antiquus, especially in the talonid basin, which shows a very complex set of ridges in the specimens from La Bouffie. In general, the trigonid is wider in the $\mathrm{M}_{2}$ and $\mathrm{M}_{3}$ of $N$. antiquus, being as wide as the talonid in some $\mathrm{M}_{2}$ and even wider than the talonid in some $\mathrm{M}_{3}$ from La Bouffie. Moreover, the cristids running buccally from the paraconid-metaconid complex and lingually from the protoconid are better developed in the $\mathrm{M}_{2}$ and $\mathrm{M}_{3}$ of $N$. antiquus, joining, in some specimens, to form a single cristid that crosses the trigonid transversally. In the $\mathrm{M}_{3}$, the hypoconulid lobe is longer and better differentiated from the talonid basin in N. antiquus than in $N$. aff. anadoni from VDR. In the $\mathrm{I}^{1}$ of $N$. aff. anadoni from VDR, the talon is more prominent than in the specimens of $N$. antiquus. The upper canines and premolars of $N$. antiquus have sharper cristae and more marked cingula than those of $N$. aff. anadoni from VDR. Furthermore, the $\mathrm{P}^{2}$ of $N$. antiquus have a more accentuated distolingual expansion than those of $N$. aff. anadoni. The $\mathrm{P}^{3}$ of $N$. antiquus have clearly betterdeveloped protocones and mesastyles than those of $N$. aff. anadoni from VDR. The $\mathrm{P}^{4}$ of $N$. antiquus from La Bouffie differ from those of $N$. aff. anadoni in the more developed protocone, parastyle and metastyle and in the much more accentuated enamel wrinkling on the lingual slope of the paracone. The $\mathrm{M}^{1-2}$ of $N$. antiquus differ from those of $N$. aff. anadoni in having larger conules (including a tubercular lingual metaconule), a broader talon basin and, in nearly all cases, a connection between the postprotocrista and the hypocone (Fig. 6M-O). The hypocone occupies a more marginal position in the $\mathrm{M}^{1-2}$ of $N$. antiquus. The $\mathrm{M}^{3}$ of $N$. antiquus have more developed conules than those of $N$. aff. anadoni from VDR; in addition, they are much more distolingually expanded and show a broad talon basin, which is absent or very reduced in the molars from VDR (Fig. $6 \mathrm{~K}$ and P). Moreover, the enamel wrinkling is much more complex in the upper molars of $N$. antiquus than in $N$. aff. anadoni, with sharper crests directed from the main cusps towards the trigon basin, additional transverse crests descending from the paraconule and metaconules, and marked crenulation on the talon basin.

The species Necrolemur zitteli is known from only a right mandible with $\mathrm{P}_{3}-\mathrm{M}_{3}$ of unknown provenience, although, according to several authors, it most probably came from the Quercy phosphorites (Stehlin, 1916; Godinot, 1983). N. zitteli is notably smaller than N. aff. anadoni from VDR (Fig. 5). Morphologically, the most important difference is the position of the protoconid of the $\mathrm{M}_{2}$ and $\mathrm{M}_{3}$, which is placed in a more buccal position in N. zitteli than in $N$. aff. anadoni from VDR; therefore, the trigonid is clearly wider in $N$. zitteli. Moreover, the hypoconulid lobe is longer and wider in the $\mathrm{M}_{3}$ from VDR than in N. zitteli.

The single tooth of Necrolemur from VDR studied by Becker et al. (2013) is a lower incisor, which does not allow comparison with the sample depicted in this paper. In any case, according to those authors, this $\mathrm{I}_{1}$ is rather small, plotting out of the range of $N$. antiquus. It is, hence, very probable that this incisor corresponds to the form assigned here to $N$. aff. anadoni.

\subsection{Remarks on the genus Necrolemur}

Described in the 19th century on the basis of the abundant and well-preserved material found in the Quercy fissure fillings, the genus Necrolemur is frequent in Middle and Late Eocene European sites. Necrolemur shows size and morphological features that are intermediate between those of Nannopithex and Microchoerus: it mainly differs from Nannopithex in its larger size, more developed hypocone generally connected to the protocone, and double metaconule in the upper molars, wider trigonid and absence of a well developed paraconid in the $\mathrm{M}_{2}$ and $\mathrm{M}_{3}$. Necrolemur can be distinguished from Microchoerus by its smaller size, less accentuated enamel wrinkling, absent or very small mesoconid and hypoconulid in the $\mathrm{M}_{1}$ and $\mathrm{M}_{2}$, less developed metaconules and paraconule, and by the absence of the mesostyle that is present in the upper molars of almost all the species of Microchoerus (with the exception of Microchoerus hookeri, see Minwer-Barakat et al., 2017).

The best known species is $N$. antiquus, well-represented in Robiacian and Headonian localities ranging from MP16 to MP18, such as Le Bretou, Lavergne, La Bouffie, Mormont-Eclepens, Dielsdorf or Les Pradigues (Godinot, 1983, 1985, 2003; Hooker and Weidmann, 2000). In contrast, the species $N$. zitteli is known from only a single mandibular fragment of unknown age and provenance. The recent description of $N$. anadoni from Sant Jaume de Frontanyà- 1 in the Pyrenees has shed new light on the relationships among the different species of microchoerines from the Middle and Late Eocene of Europe (Minwer-Barakat et al., 2015a). According to this study, N. anadoni is a direct descendant of Nannopithex filholi and the ancestor of $N$. antiquus, an interpretation supported by the stratocladistic analysis performed in that work. Clear directional trends can be observed in the lineage that leads from $N$. filholi to N. anadoni, N. antiquus, M. hookeri and, finally, Microchoerus erinaceus, including an increase in size, a progressive broadening of the trigonid and a reduction of the paraconid in the $\mathrm{M}_{2}$ and $\mathrm{M}_{3}$, an enlargement of the hypocone, paraconule and metaconules in the upper molars, a better development of the connection between hypocone and protocone in the $\mathrm{M}^{1-2}$, a distolingual expansion of the $\mathrm{M}^{3}$ and an accentuation of the enamel wrinkling from the oldest to youngest species (Minwer-Barakat et al., 2015a, 2017).

The sample of $N$. aff. anadoni from VDR fits perfectly in this evolutionary scheme, occupying an intermediate position between N. anadoni from SJF-1 and N. antiquus from several European localities. The size and overall morphology of the teeth from VDR resemble those of $N$. anadoni from SJF-1, although there are some morphological differences that preclude a definitive ascription of the material from VDR to that species and that are similar to the later $N$. antiquus (Table 2, Fig. 6). In general terms, the conules of the upper molars of $N$. aff. anadoni are more developed than in $N$. anadoni but smaller than in N. antiquus. Furthermore, the lingual metaconule is typically crestiform in N. anadoni (Fig. 6B-D) and tubercular in N. antiquus (Fig. 6M-O); in the sample from VDR, it is crestiform in half of the $\mathrm{M}^{1-2}$ and tubercular in the other half. Moreover, the protoconid in the $\mathrm{M}_{2}$ and $\mathrm{M}_{3}$ from VDR occupies a position that is slightly more buccal than in the lower molars of $N$. anadoni from SJF and, in general, more lingual than in those of $N$. antiquus from La Bouffie, so the trigonid of $N$. aff. anadoni is wider than in $N$. anadoni and narrower than in N. antiquus. In addition, the paraconid is a distinct cusp in the $\mathrm{M}_{2}$ and $\mathrm{M}_{3}$ of $N$. anadoni, but generally fused to the metaconid in $N$. aff. anadoni from VDR and N. antiquus. The hypoconulid lobe of the $\mathrm{M}_{3}$ of $N$. aff. anadoni is longer than in $N$. anadoni but shorter than in N. antiquus. Other features, such as the enamel wrinkling and the frequency of the connection between postprotocrista and hypocone, are very similar in $N$. aff. anadoni and $N$. anadoni, and clearly different from N. antiquus (Fig. 6).

Summarizing, all these observations indicate that the sample of Necrolemur from VDR is essentially similar to N. anadoni from SJF, but displays some advanced features pointing to the morphology of $N$. antiquus, which is consistent with an intermediate position for the newly studied population and gives support to the ancestor-descendant relationship already proposed for the species N. anadoni and N. antiquus (Minwer-Barakat et al., 2015a). 


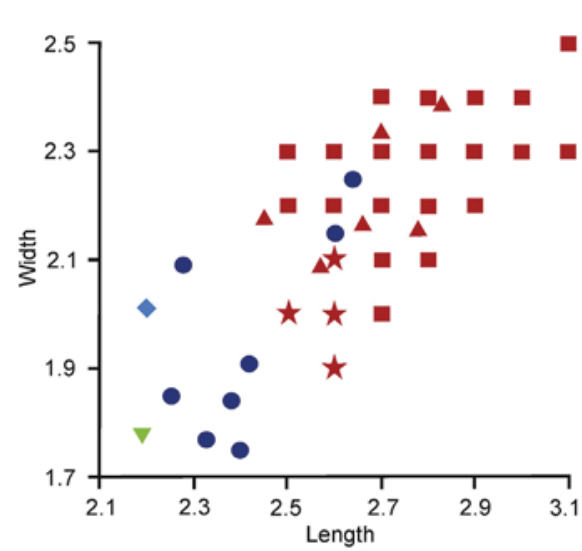

$\mathbf{M}_{1}$
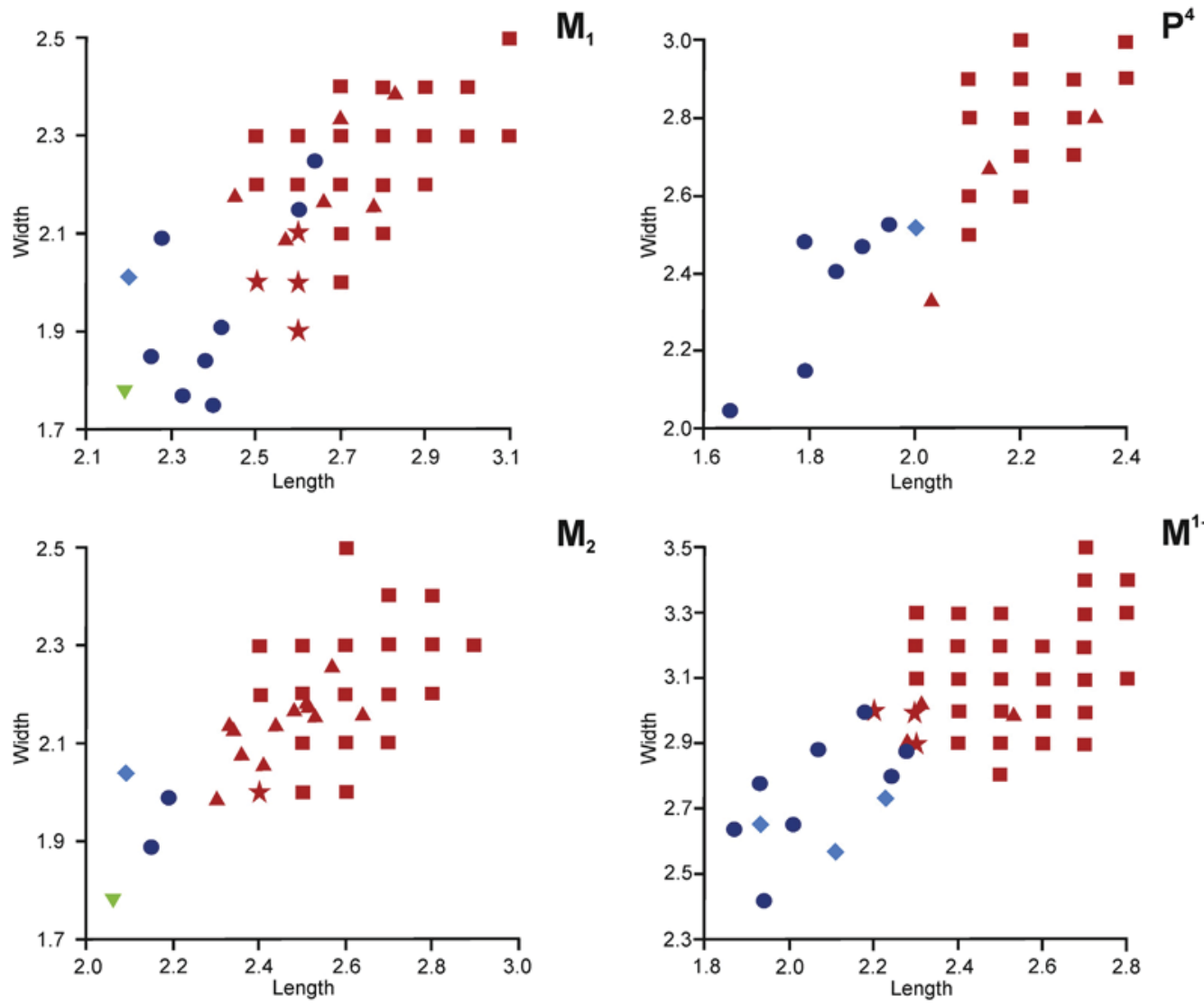

$\mathbf{M}_{2}$
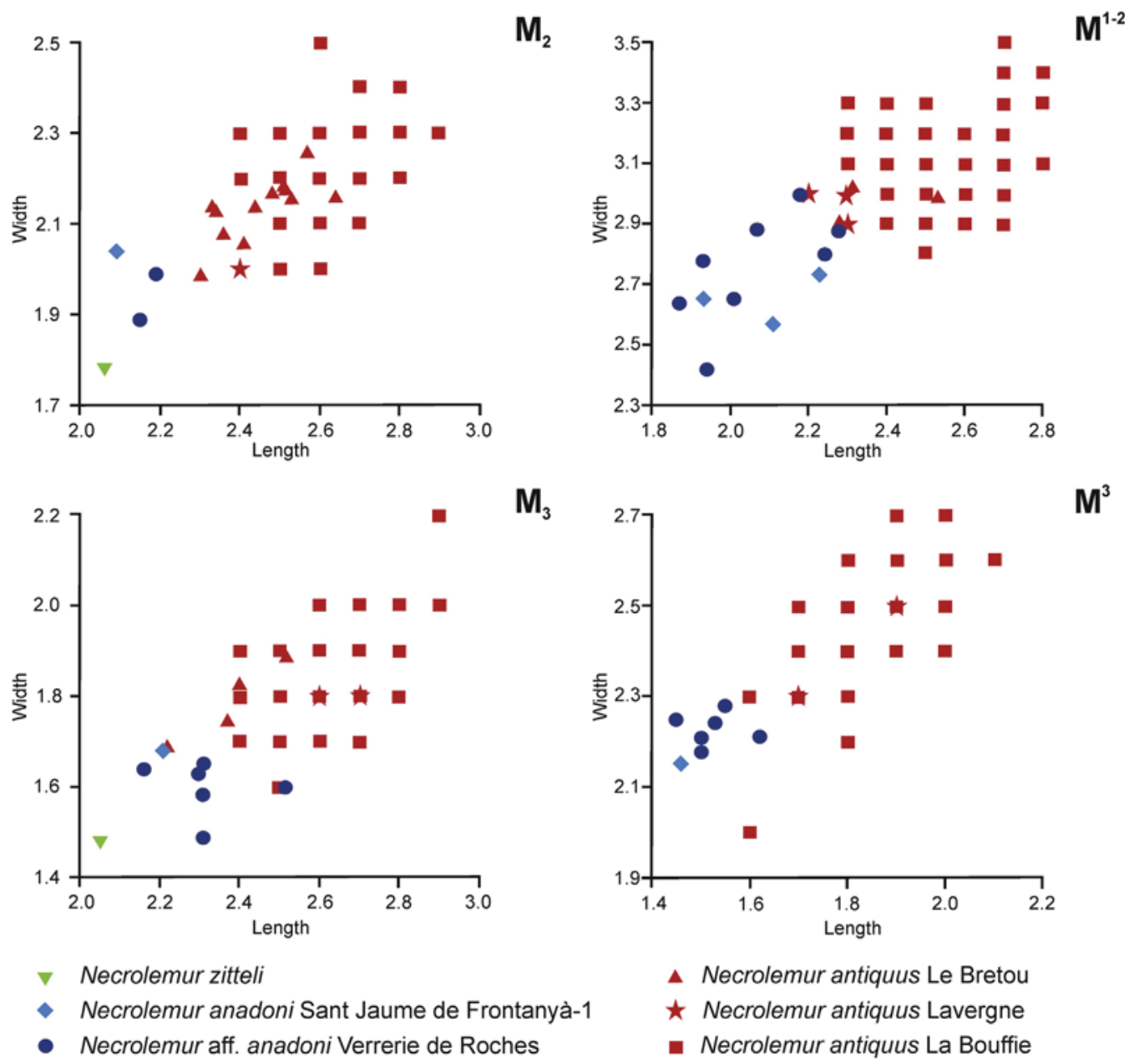
- Necrolemur antiquus Le Bretou
$\star$ Necrolemur antiquus Lavergne
- Necrolemur antiquus La Bouffie

Figure 5. Size graphs (length $\times$ width) of the $\mathrm{M}_{1}, \mathrm{M}_{2}, \mathrm{M}_{3}, \mathrm{P}^{4}, \mathrm{M}^{1-2}$ and $\mathrm{M}^{3}$ of Necrolemur zitteli, Necrolemur anadoni, Necrolemur aff. anadoni and Necrolemur antiquus. Measurements of $N$. aff. anadoni from La Verrerie de Roches are those presented in this work. Measurements of $N$. zittteli have been taken directly on a cast of the holotype. Data from $N$. anadoni from Sant Jaume de Frontanyà after Minwer-Barakat et al. (2015a). Data from N. antiquus from Le Bretou, Lavergne and La Bouffie after Godinot (1983).

Genus PSEUDOLORIS Stehlin, 1916.

Pseudoloris pyrenaicus Minwer-Barakat et al., 2010

Fig. 7A-J

\subsection{Description}

$\mathbf{M}_{1-2}$ : The trigonid is relatively long. The protoconid is in a notably more mesial position than the metaconid. The paracristid continues in a low premetacristid that joins the metaconid, closing completely the trigonid basin lingually. There is not a distinct paraconid, but in specimen NMB V.R.117 the paracristid is somewhat thickened at the mesiolingual extreme of the tooth (Fig. 7A). The cristid obliqua is relatively thick. The entoconid and hypoconid are voluminous and similar in height to each other. The hypoconulid is pointed and equidistant between the entoconid and hypoconid. The buccal cingulid is well marked in NMB V.R.120 and weaker in NMB V.R.117.

$\mathbf{P}^{\mathbf{3}}$ : The outline is triangular, with the buccal border longer than the lingual one. The mesial border is nearly straight and the distal border is concave. The paracone is high and pointed. The 
A
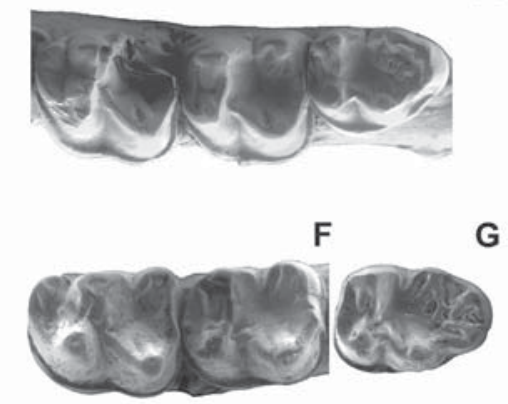

G

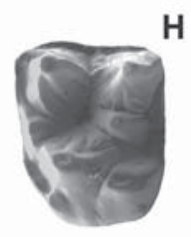

H

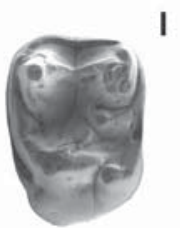

C

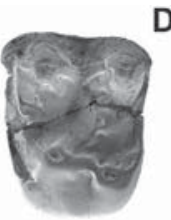

D
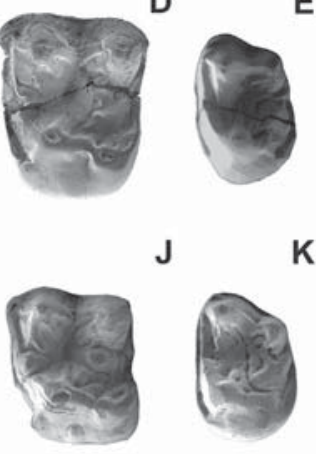

L

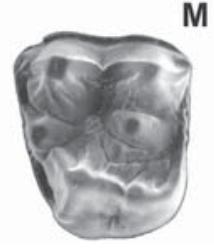

M

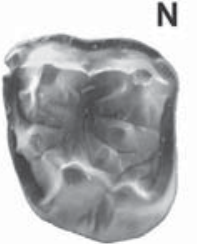

N

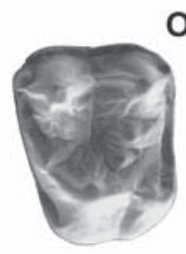

O P

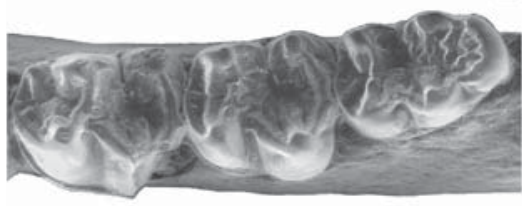

Figure 6. Comparative images of the lower and upper molars of Necrolemur anadoni from Sant Jaume de Frontanyà-1 (A-E), Necrolemur aff. anadoni from La Verrerie de Roches $(\mathrm{F}-\mathrm{K})$ and Necrolemur antiquus from La Bouffie (L-P). ESEM images of the material from Sant Jaume de Frontanyà and La Verrerie de Roches were taken directly of the specimens; images of $N$. antiquus were taken of high quality casts of the original specimens curated in the Université de Montpellier (France). Some specimens are reversed for comparison. A:

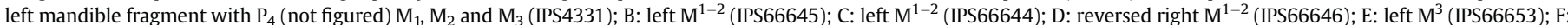
left mandible fragment with $\mathrm{M}_{1}-\mathrm{M}_{2}$ (NMB V.R.61); $\mathrm{G}$ : left $\mathrm{M}_{3}$ (NMB V.R.55); H: reversed right $\mathrm{M}^{1-2}$ (NMB V.R.96); I: left $\mathrm{M}^{1-2}$ (NMB V.R.91); J: reversed right $\mathrm{M}^{1-2}$ (NMB V.R.107); K: reversed right $\mathrm{M}^{3}$ (NMB V.R.101); L: reversed right mandible fragment with $\mathrm{P}_{4}$ (not figured) $\mathrm{M}_{1}, \mathrm{M}_{2}$ and $\mathrm{M}_{3}$ (BFI 71); $\mathrm{M}$ : left $\mathrm{M}^{1-2}$ (BFI 138); N: left $\mathrm{M}^{1-2}$ (BFI 112); O: left $\mathrm{M}^{1-2}$ (BFI 153); P: left $\mathrm{M}^{3}$ (BFI 211). Scale bar represents $1 \mathrm{~mm}$.

Table 2

Character states of different morphological traits in the teeth of the microchoerine species Nannopithex filholi, Necrolemur anadoni, Necrolemur aff. anadoni from La Verrerie de Roches (VDR), Necrolemur antiquus, Microchoerus hookeri and Microchoerus erinaceus.

\begin{tabular}{|c|c|c|c|c|c|c|}
\hline & $\begin{array}{l}\text { Nannopithex } \\
\text { filholi }\end{array}$ & $\begin{array}{l}\text { Necrolemur } \\
\text { anadoni }\end{array}$ & $\begin{array}{l}\text { Necrolemur aff. } \\
\text { anadoni VDR }\end{array}$ & Necrolemur antiquus & Microchoerus hookeri & Microchoerus erinaceus \\
\hline $\mathrm{M}_{1}$ and $\mathrm{M}_{2}$ hypoconulid & Absent & Absent & Absent & $\begin{array}{l}\text { Sometimes } \\
\text { present, small }\end{array}$ & $\begin{array}{l}\text { Small and single; } \\
\text { rarely double }(<5 \%)\end{array}$ & Large, single or double \\
\hline $\mathrm{M}_{1}$ and $\mathrm{M}_{2}$ mesoconid & Absent & Absent & Absent & Absent & Generally absent $(<25 \%)$ & Present, single or double \\
\hline $\mathrm{M}_{2}$ and $\mathrm{M}_{3}$ paraconid & $\begin{array}{l}\text { Often well } \\
\text { separated from } \\
\text { the metaconid }\end{array}$ & $\begin{array}{l}\text { Very small and } \\
\text { attached to the } \\
\text { metaconid }\end{array}$ & $\begin{array}{l}\text { Only distinct in } \\
\text { some specimens }\end{array}$ & Generally absent & Absent & Absent \\
\hline $\mathrm{M}_{2}$ and $\mathrm{M}_{3}$ trigonid & Very narrow & $\begin{array}{l}\text { Clearly narrower } \\
\text { than the talonid }\end{array}$ & $\begin{array}{l}\text { Narrower than } \\
\text { the talonid }\end{array}$ & Relatively wide & Relatively wide & Relatively wide \\
\hline $\mathrm{P}^{3}$ and $\mathrm{P}^{4}$ hypocone & Absent & Absent & Absent & Absent & Absent & Present \\
\hline $\mathrm{M}^{1-2}$ hypocone size & Small & Large & Large & Large & Very large & Very large \\
\hline $\begin{array}{l}\mathrm{M}^{1-2} \text { protocone-hypocone } \\
\text { connection }\end{array}$ & Absent & Weak & Weak & Usually strong & Strong & Strong \\
\hline $\begin{array}{l}\mathrm{M}^{1-2} \text { metaconule } \\
\quad \text { (single or double) }\end{array}$ & Single & Double & Double & Double & Double & Double \\
\hline $\begin{array}{l}\text { Shape of the lingual } \\
\text { metaconule in } \mathrm{M}^{1-2}\end{array}$ & - & Crest-shaped & $\begin{array}{l}\text { Crest-shaped or } \\
\text { tubercular }\end{array}$ & Tubercular & Tubercular & Tubercular \\
\hline $\mathrm{M}^{1-2}$ mesostyle (presence) & Absent & Absent & Absent & Absent & Generally absent $(<25 \%)$ & Always present \\
\hline $\begin{array}{l}\mathrm{M}^{1-2} \text { mesostyle } \\
\quad \text { (size and shape) }\end{array}$ & - & - & - & - & Weak, crest-shaped & Strong, generally tubercular \\
\hline $\mathrm{M}^{1-2}$ hypostyle & Absent & Absent & Absent & Absent & Absent & Present \\
\hline $\mathrm{M}^{3}$ shape & $\begin{array}{l}\text { Very short, } \\
\text { without } \\
\text { distinct } \\
\text { talon basin }\end{array}$ & $\begin{array}{l}\text { Short, without } \\
\text { distinct talon } \\
\text { basin }\end{array}$ & $\begin{array}{l}\text { Talon basin very } \\
\text { reduced or absent }\end{array}$ & $\begin{array}{l}\text { Slightly enlarged } \\
\text { distolingually, with } \\
\text { a distinct talon basin }\end{array}$ & $\begin{array}{l}\text { Enlarged distolingually, } \\
\text { with a well-defined } \\
\text { talon basin }\end{array}$ & $\begin{array}{l}\text { Very enlarged distolingually, } \\
\text { with a broad talon basin }\end{array}$ \\
\hline $\begin{array}{l}\text { Enamel wrinkling } \\
\text { in molars and } \\
\text { premolars }\end{array}$ & Very weak & Weak & Weak & Moderate to complex & Complex & Very complex \\
\hline
\end{tabular}

anterocrista is short and straight. The posterocrista is longer than the anterocrista and curved buccally. Parastyle and metastyle are absent. The lingual lobe is broad. The protocone is very reduced and placed in mesiolingual position. There is a strong cingulum surrounding the entire crown.
$\mathbf{M}^{\mathbf{1}-\mathbf{2}}$ : Paracone and metacone are similar in height and higher than the protocone. The mesiobuccal corner of the tooth is damaged, but a minuscule parastyle is observable. There is no metastyle. The hypocone is very reduced, to a thickening at the lingual end of the postcingulum, and completely isolated from the 

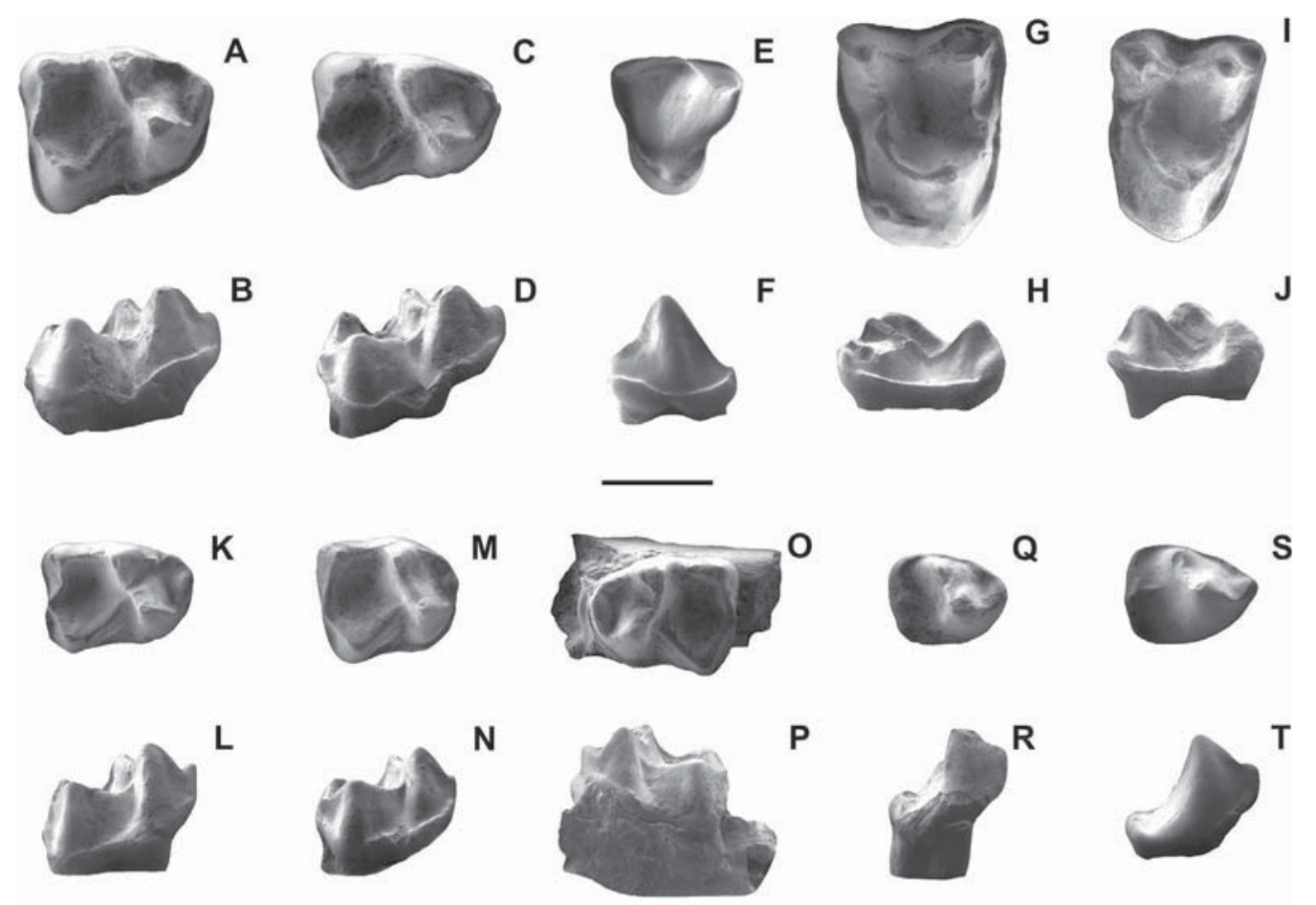

U
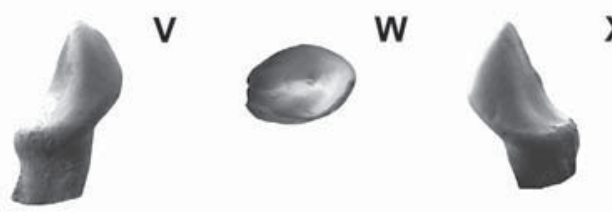

$\mathbf{X}$

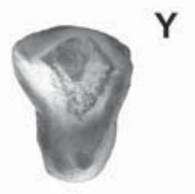

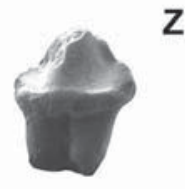

Figure 7. ESEM images of the teeth of Pseudoloris pyrenaicus Minwer-Barakat et al., 2010 (A-J) and Pseudoloris parvulus (Filhol, 1890) (K-Z) from La Verrerie de Roches. A-B: right $\mathrm{M}_{1-2}$ (NMB V.R.117) in occlusal (A) and buccal (B) views; C-D: right $\mathrm{M}_{1-2}$ (NMB V.R.120) in occlusal (C) and buccal (D) views; E-F: left $\mathrm{P}^{3}$ (NMB V.R.124) in occlusal (E) and buccal (F) views; G-H: right $\mathrm{M}^{1-2}$ (NMB V.R.114) in occlusal (G) and buccal (H) views; I-J: right $\mathrm{M}^{3}$ (NMB V.R.112) in occlusal (I) and buccal (J) views; $\mathrm{K}-\mathrm{L}$ : right $\mathrm{M}_{1-2}$ (NMB V.R.118) in occlusal $(\mathrm{K})$ and buccal $(\mathrm{L})$ views; $\mathrm{M}-\mathrm{N}$ : right $\mathrm{M}_{1-2}$ (NMB V.R.119) in occlusal $(\mathrm{M})$ and buccal (N) views; O-P: left $\mathrm{M}_{1-2}$ (NMB V.R.116) in occlusal (O) and buccal (P) views; $\mathrm{Q}-\mathrm{R}$ : right $\mathrm{P}_{4}$ (NMB V.R.113) in occlusal (Q) and buccal (R) views; S-T: right $\mathrm{P}_{4}$ (NMB V.R.115) in occlusal (S) and buccal (T) views; U-V: left C ${ }^{1}$ (NMB V.R.122) in occlusal (U) and buccal (V) views; $\mathrm{W}-\mathrm{X}$ : right $\mathrm{C}^{1}$ (NMB V.R.123) in occlusal $(\mathrm{W})$ and buccal $(\mathrm{X})$ views; $\mathrm{Y}-\mathrm{Z}$ : right $\mathrm{P}^{4}$ (NMB V.R.111) in occlusal (Y) and buccal (Z) views. Scale bar represents 1 mm.

protocone. The paraconule is small, and bears a long preparaconule crista and a short postparaconule crista that enclose a small basin on the mesiolingual base of the paracone. The metaconule is slightly larger than the paraconule. There are no distinct premetaconule and postmetaconule cristae, but only a weak crista running buccally from the metaconule towards the metacone. The precingulum starts at the mesiolingual corner of the tooth and joins the preparaconule crista. The postcingulum and the buccal cingulum are stronger than the precingulum, and occupy the entire distal and buccal borders, respectively. There is also a shorter and weaker cingulum on the lingual border, from the hypocone to the distolingual base of the protocone.

$\mathbf{M}^{\mathbf{3}}$ : The outline is triangular. The paracone is slightly larger than the metacone. The preparacrista is directed mesially and connected to a distinct parastyle. The postmetacrista is directed distobuccally. A metastyle is absent. The paraconule is very small. The preparaconule crista is long and reaches the parastyle. The metaconule is larger than the paraconule. The premetaconule crista is weak, and there is no postmetaconule crista. There is no hypocone. The precingulum, postcingulum and buccal cingulum are well developed.

\subsection{Measurements}

See Table 3.

\subsection{Comparisons}

The material from La Verrerie de Roches is very similar to that of P. pyrenaicus from Sant Jaume de Frontanyà-3C and 3D (MinwerBarakat et al., 2010). The lower molars are slightly larger in VDR (Fig. 8), but morphologically identical to those of SJF. The $\mathrm{P}^{3}$ from VDR resembles the single specimen from SJF-3C, both displaying a very reduced protocone. The $\mathrm{M}^{1-2}$ from VDR shows the most distinctive feature of the upper molars of $P$. pyrenaicus from SFJ-3C and $3 \mathrm{D}$, a very reduced hypocone, resembling a thickening of the postcingulum. The only observable difference is the metaconule, which is crescentiform and bears distinct premetaconule and postmetaconule cristae in the molars from SJF, and is less developed in VDR. The $\mathrm{M}^{3}$ from VDR is somewhat larger than those from SJF-3C and 3D, but very similar in morphology.

All the teeth of $P$. pyrenaicus from VDR are notably larger than those of Pseudoloris parvulus from several European localities, such as Hordle Cliff in England (Cray, 1973), Le Bretou, Perrière and La Bouffie in France (Godinot, 1983, 1988a), Eclépens-B in Switzerland (Hooker and Weidmann, 2000) and Sossís in Spain (MinwerBarakat et al., 2015b; Fig. 8). There are also clear morphological differences between these species, especially in the upper dentition: the $\mathrm{P}^{3}$ of $P$. pyrenaicus from VDR has a much more reduced protocone than found on the teeth of $P$. parvulus; the $M^{1-2}$ from 
Table 3

Measurements (in mm) of the teeth of Pseudoloris pyrenaicus Minwer-Barakat et al. 2010 and Pseudoloris parvulus (Filhol, 1890) from La Verrerie de Roches. L': length perpendicular to the root axis; $\mathrm{H}^{\prime}$ : height parallel to the root axis.

\begin{tabular}{llllllll}
\hline Species & Catalog number & Tooth & Length & Width & Height & $\mathrm{L}^{\prime}$ & $\mathrm{H}^{\prime}$ \\
\hline Pseudoloris & NMB V.R. 117 & $\mathrm{M}_{1-2}$ & 1.76 & 1.48 & & & \\
pyrenaicus & NMB V.R. 120 & $\mathrm{M}_{1-2}$ & 1.76 & 1.38 & & & \\
& NMB V.R. 124 & $\mathrm{P}^{3}$ & 1.24 & 1.30 & & & \\
& NMB V.R. 114 & $\mathrm{M}^{1-2}$ & 1.56 & 2.10 & & & \\
& NMB V.R. 112 & $\mathrm{M}^{3}$ & 1.43 & 1.96 & & & \\
Pseudoloris & NMB V.R. 113 & $\mathrm{P}_{4}$ & 1.27 & 0.91 & 0.76 & & \\
parvulus & NMB V.R. 115 & $\mathrm{P}_{4}$ & 1.34 & 0.93 & 0.80 & & \\
& NMB V.R. 116 & $\mathrm{M}_{1-2}$ & 1.37 & 1.15 & & & \\
& NMB V.R. 118 & $\mathrm{M}_{1-2}$ & 1.40 & 1.10 & & & \\
& NMB V.R. 119 & $\mathrm{M}_{1-2}$ & 1.29 & 1.21 & & & \\
& NMB V.R. 122 & $\mathrm{C}^{1}$ & 1.27 & 0.66 & 0.77 & 0.99 & 1.15 \\
& NMB V.R. 123 & $\mathrm{C}^{1}$ & 1.25 & 0.72 & 0.86 & 1.03 & 1.24 \\
& NMB V.R. 111 & $\mathrm{P}^{4}$ & 1.09 & 1.37 & & & \\
\hline
\end{tabular}

VDR has a clearly smaller hypocone, and both the $\mathrm{M}^{1-2}$ and the $\mathrm{M}^{3}$ have less developed metaconules than those on the upper molars of $P$. parvulus. In addition, the lower molars of $P$. pyrenaicus have proportionally longer trigonids and higher paracristids than those of $P$. parvulus.

The lower molars of P. pyrenaicus from VDR are larger than those of $P$. saalae from Geiseltal-Obere Mittelkohle (Thalmann, 1994) and P. isabenae from Capella (Crusafont-Pairó, 1967), and lack the paraconid that is present in these two species. Furthermore, in the molars of $P$. saalae the cristid obliqua ends in a more buccal position than in those of P. pyrenaicus. The main difference with Pseudoloris reguanti from Sant Cugat de Gavadons is size, smaller in P. pyrenaicus from VDR (Minwer-Barakat et al., 2013a). The teeth of P. pyrenaicus from VDR are larger than those of Pseudoloris cuestai from Mazaterón (Minwer-Barakat et al., 2012). In addition, the hypocone is better developed in the only $\mathrm{M}^{1-2}$ of $P$. cuestai than in that of $P$. pyrenaicus.
The main difference with $P$. crusafonti from Grisolles (Louis and Sudre, 1975) is the morphology of the $\mathrm{M}^{1-2}$, which in P. crusafonti has a much more developed hypocone, paraconule and metaconule than in P. pyrenaicus from VDR. Moreover, the metaconule of the $\mathrm{M}^{1-2}$ of $P$. crusafonti is crescentiform, bearing distinct premetaconule and postmetaconule cristae, which are absent in the single specimen from VDR.

There are clear differences between $P$. pyrenaicus from VDR and Pseudoloris godinoti from Fonollosa-13 (Köhler and Moyà-Solà, 1999). The lower molars of $P$. pyrenaicus from VDR have the trigonid basin closed lingually, and lack the distinct paraconid that is present in the only $\mathrm{M}_{1}$ of $P$. godinoti. The $\mathrm{P}^{3}$ of $P$. godinoti is notably higher-crowned, and has a better differentiated protocone than the specimen from VDR. Finally, the $\mathrm{M}^{1}$ of $P$. godinoti differs from that of $P$. pyrenaicus from VDR in the much larger hypocone, the betterdeveloped paraconule and metaconule, the more reduced trigon basin and the presence of a long and prominent metastyle.

Pseudoloris parvulus (Filhol, 1890)

Fig. $7 \mathrm{~K}-\mathrm{Z}$

\subsection{Description}

$\mathbf{P}_{\mathbf{4}}$ : The protoconid is high. The paracristid runs mesially from the protoconid, curves lingually, and thickens at its mesiolingual end, without forming a distinct paraconid. There is a straight protocristid connecting the protoconid to a small metaconid. The lingual cingulid is continuous. The distal cingulid is very thick. There is a short and sharp longitudinal cristid in the talonid, attached to the distal cingulid. There is no buccal cingulid.

$\mathbf{M}_{1-2}$ : The main cusps are pointed. The protoconid is somewhat higher than the metaconid; these cusps are connected by a protocristid that in two out of three specimens shows a trigonid notch. The paracristid is sharp and very low, especially in specimens NMB V.R.116 and 119 (Fig. 7M-P). There is no sign of a paraconid. In two
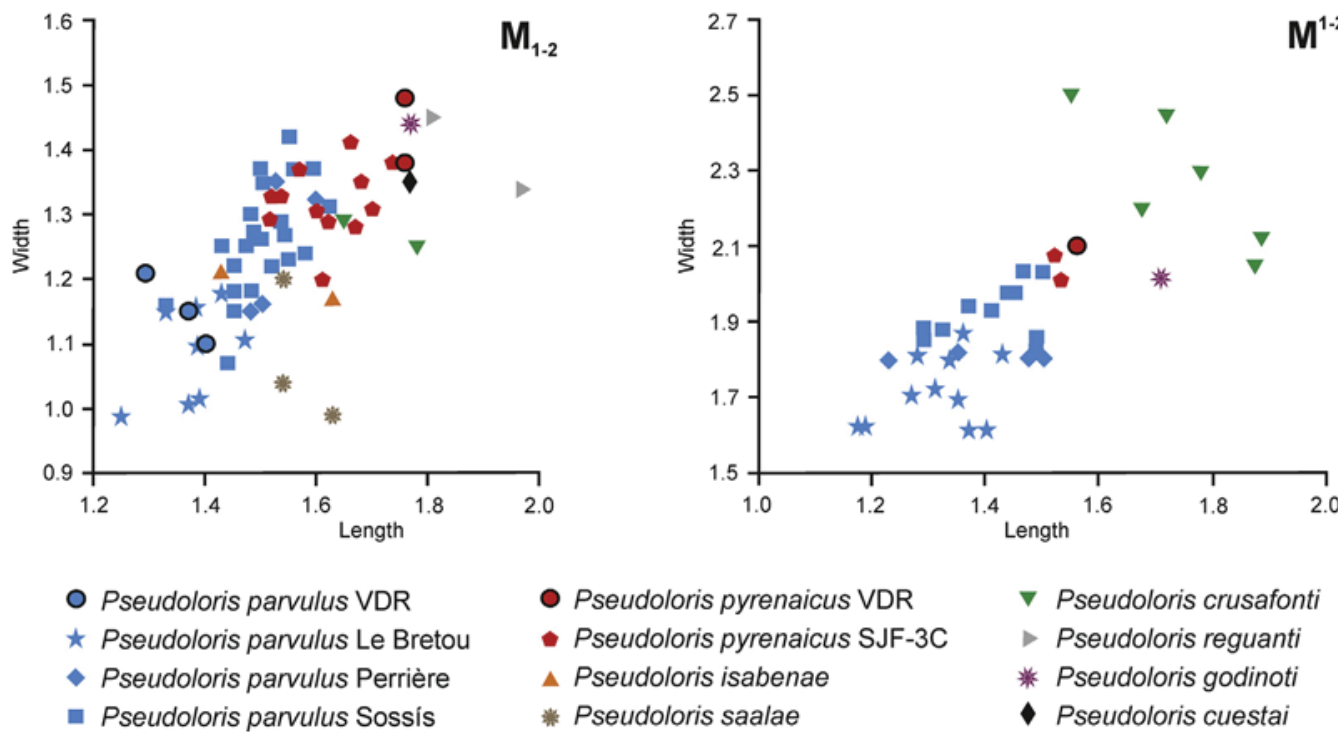

- Pseudoloris pyrenaicus VDR

- Pseudoloris pyrenaicus SJF-3C

- Pseudoloris isabenae

* Pseudoloris saalae

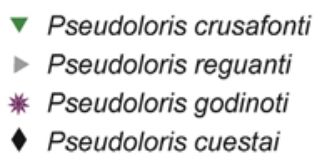

Figure 8. Size graphs (length $\times$ width) of the $\mathrm{M}_{1-2}$ and $\mathrm{M}^{1-2}$ of the different species of the genus Pseudoloris. Measurements of $P$. parvulus and $P$. pyrenaicus from La Verrerie de Roches are those presented in this work. Measurements of $P$. isabenae from Capella have been taken directly from the holotype, stored at the Institut Català de Paleontologia Miquel Crusafont; lengths are approximate, since the teeth are in the mandible and it is not possible to estimate the exact length due to their overlap in occlusal view. Data for $P$. parvulus from Le Bretou and Perrière after Godinot (1983); data for $P$. parvulus from Sossís after Minwer-Barakat et al. (2015b); data for $P$. pyrenaicus from Sant Jaume de Frontanyà-3C after Minwer-Barakat et al. (2010); data for P. saalae from Geiseltal-Obere Mittelkohle after Thalmann (1994); data for P. crusafonti from Grisolles after Louis and Sudre (1975); data for P. reguanti from Sant Cugat de Gavadons after Minwer-Barakat et al. (2013a); data for P. godinoti from Fonollosa-13 after Köhler and Moyà-Solà (1999); data for P. cuestai from Mazaterón after Minwer-Barakat et al. (2012). 
teeth the paracristid continues in a sharp premetacristid that connects to the metaconid, closing the trigonid basin lingually. In the other one, the premetacristid does not join the paracristid and the trigonid basin is partially open lingually (Fig. 7K). The cristid obliqua is sharp and ends at the level of the trigonid notch in one specimen and on the distal side of the protoconid in the other two teeth. The hypoconulid is prominent and situated in a central position between the entoconid and hypoconid. The buccal cingulid starts at the middle of the mesial side of the tooth, surrounds the buccal border and ends at the level of the hypoconulid in one specimen, reaching the distolingual corner of the tooth in the other two. There is no lingual cingulid.

$\mathbf{C}^{\mathbf{1}}$ : The outline is elliptical, clearly longer than wide. The base of the enamel rises at the mesial side of the tooth. The apex is pointed. Both the anterocrista and the posterocrista are sharp. The anterocrista continues in a well-marked lingual cingulum that surrounds the lingual border. A much weaker cingulum is observed on the distobuccal base of the tooth.

$\mathbf{P}^{\mathbf{4}}$ : A small premolar, clearly wider than long. The paracone is high. The anterocrista is short and directed mesially. The posterocrista runs distally from the paracone and curves buccally, forming a distinct metastyle. The lingual lobe is broad and bears a perfectly differentiated, pointed protocone. The precingulum and the postcingulum connect to the protocone. There is also a weak cingulum occupying the entire buccal border.

\subsection{Comparisons}

The teeth of $P$. parvulus from La Verrerie de Roches are similar to those of the same species from other localities. The specimens from VRD are identical in size to those of $P$. parvulus from Le Bretou (MP16, Godinot, 1988a), and slightly smaller than those from other more recent localities, such as Perrière and Sossís (MP17, Godinot, 1983; Minwer-Barakat et al., 2015b, Fig. 8). There are no significant morphological differences between the lower molars, the $C^{1}$ and the $\mathrm{P}^{4}$ of $P$. parvulus from VDR and those from other samples of the same species. The only observed difference is the presence of a cristid that runs distobuccally from the protoconid, delimitating a deep talonid basin, in the $\mathrm{P}_{4}$ of $P$. parvulus from other sites such as Sossís (Minwer-Barakat et al., 2015b). This cristid is barely marked in specimen NMB V.R.113 from VDR and absent in NMB V.R.115.

All the teeth from VDR attributed to $P$. parvulus are markedly smaller than those of Pseudoloris pyrenaicus from Sant Jaume de Frontanyà-3C and 3D (Fig. 8). Moreover, in the lower molars of
$P$. pyrenaicus the paracrisitid is notably higher and thicker than in those of $P$. parvulus from VDR. Furthermore, the protocone is more developed in the $\mathrm{P}^{4}$ of $P$. parvulus from VDR than in the premolars of $P$. pyrenaicus from SJF.

The lower molars and the $\mathrm{P}^{4}$ of $P$. parvulus from VDR are markedly smaller than those of $P$. godinoti from Fonollosa-13 (Köhler and Moyà-Solà, 1999), P. crusafonti from Grisolles (Louis and Sudre, 1975) and P. cuestai from Mazaterón (Minwer-Barakat et al., 2012). Furthermore, the single $\mathrm{M}_{1}$ of $P$. godinoti displays a distinct paraconid that is absent in the molars from VDR.

The species $P$. saalae, $P$. isabenae and $P$. reguanti are known from only their lower dentition. P. parvulus from VDR mainly differs from $P$. reguanti in the much smaller size (Minwer-Barakat et al., 2013a). The lower molars of $P$. saalae and $P$. isabenae have a distinct paraconid that is absent in P. parvulus, and the cristid obliqua of $P$. saalae occupies a more buccal position than in P. parvulus.

\subsection{Remarks on the genus Pseudoloris}

The great difference in size among the lower molars of Pseudoloris from La Verrerie de Roches evidences the presence of two species (Fig. 8). The smallest molars (NMB V.R.116, 118 and 119) fit the size range of $P$. parvulus (they resemble, in particular, those from Le Bretou), and are smaller than those of the rest of known species of Pseudoloris. Their morphology, with sharp and low paracristids, is also similar to that of $P$. parvulus, so they can be confidently attributed to this species.

The large lower molars from La Verrerie de Roches are similar in size to those of several species of Pseudoloris (P. pyrenaicus, $P$. cuestai, P. godinoti). The $\mathrm{M}^{1-2}$ fits the size of $P$. pyrenaicus from SJF3C (Fig. 8), and displays a very reduced hypocone, a feature that is not observed in any other species of the genus. Therefore, the large form present in VDR can be assigned to $P$. pyrenaicus.

La Verrerie de Roches represents the first record of $P$. pyrenaicus outside the Iberian Peninsula and, more importantly, the first locality in which two different species of Pseudoloris have been identified. Minwer-Barakat et al. (2010, 2015b) proposed a lineage formed by the species $P$. saalae, $P$. isabenae, $P$. pyrenaicus and $P$. parvulus, thus suggesting an ancestor-descendant relationship for the last two species. Whether their presence in VDR corresponds to a mixture of remains of different ages or if these two species coexisted during the same time span will be discussed in the next section.
A
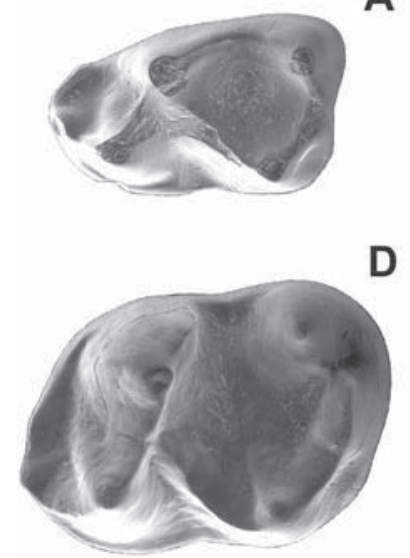

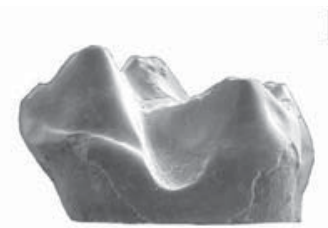

B

E

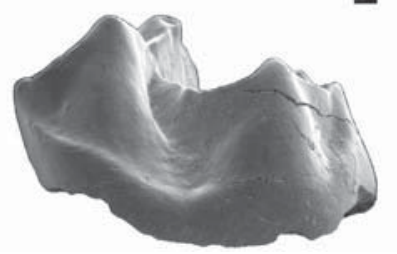

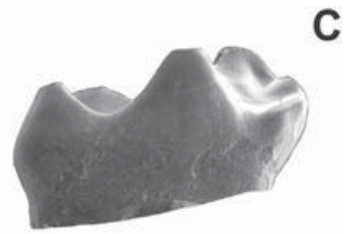

C

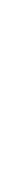

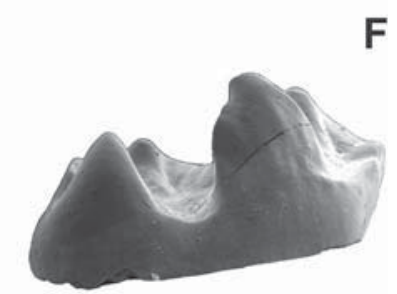

Figure 9. ESEM images of the teeth of Adapiformes from La Verrerie de Roches. A-C: left $M_{1}$ of Anchomomyini indet. (NMB V.R.125) in occlusal (A), buccal (B) and lingual (C) views; D-F: left $\mathrm{M}_{2}$ of Microadapis cf. sciureus (NMB V.R.126) in occlusal (D), buccal (E) and lingual (F) views. Scale bar represents $1 \mathrm{~mm}$. 
Suborder STREPSIRRHINI Geoffroy Saint-Hilaire, 1812 Infraorder ADAPIFORMES Hoffstetter, 1977

Family CERCAMONIINAE

Tribe ANCHOMOMYINI

Anchomomyini indet.

Fig. 9A-C

\subsection{Description}

$\mathbf{M}_{1}$ : The trigonid is narrower than the talonid. A paraconid is present on the paracristid. The paracristid does not reach the base of the metaconid, leaving the trigonid open lingually. The hypoconulid is poorly developed. The cristid obliqua reaches the buccal base of the metaconid. There is a buccal cingulid present from the buccal base of the paraconid to the base of the hypoconulid, interrupted at the base of the hypoconid.

\subsection{Measurements}

Length: $2.96 \mathrm{~mm}$; width: $1.88 \mathrm{~mm}$.

\subsection{Comparisons}

This tooth presents the typical anchomomyin morphology. It has thus been compared to all anchomomyin species for which the $\mathrm{M}_{1}$ is known. The $\mathrm{M}_{1}$ from La Verrerie de Roches overlaps in size with Mazateronodon endemicus and it is also closer in size to one specimen of Buxella prisca (Fig. 10). It is much larger than Anchomomys and Nievesia, and much smaller than Buxella magna. It is similar in length to some specimens of Periconodon huerzeleri and $P$. jaegeri, although it is much narrower.

The specimen from VDR is very similar in morphology to all $\mathrm{M}_{1}$ of Anchomomys. The paraconid is more developed and more lingual than in A. crocheti (Saint-Martin-de-Londres, MP13), A. cf. quercyi (Le Bretou, MP16) and A. gaillardi (Lissieu, MP14), and the paracristid ends more mesially than in A. gaillardi. The paraconid is similar to that of Anchomomys cf. pygmaeus from Egerkingen gamma (MP13) and $A$. cf. quercyi (MP17a, La Bouffie and Fons-1). The cristid obliqua is positioned slightly more buccally than in Anchomomys cf. pygmaeus and the paracristid ends more medially than in A. cf. quercyi. The specimen from VDR is very similar to $A$. frontanyensis from Sant Jaume de Frontanyà 3C and 3D (MP15), only differing from it in size and in the less developed buccal cingulid.

Nievesia and Mazateronodon differ from the anchomomyin found in VDR in having no paraconid in the $\mathrm{M}_{1}$, and presenting a paracristid that reaches the metaconid, closing the trigonid basin lingually. Buxella presents a much shorter trigonid in the $\mathrm{M}_{1}$ than the anchomomyin from VDR, and thus a smaller trigonid basin. Regarding Periconodon, its $\mathrm{M}_{1}$ is much broader than that from VDR, its buccal cingulid is much more developed and it is not interrupted at the level of the hypoconid. The paraconid, when present, is not well-developed, and the paracristid reaches the base of the metaconid.

\subsection{Remarks on the genus Anchomomys and other anchomomyins}

We have included comparisons of the material from La Verrerie de Roches with the genus Periconodon because it was traditionally considered an anchomomyin (Godinot, 1988b), although it has lately been considered more closely related to another group of cercamoniines including the genera Agerinia and Darwinius (Godinot, 2015).

The tribe Anchomomyini is considered now to be restricted to the genera Anchomomys, Buxella, Nievesia and Mazateronodon

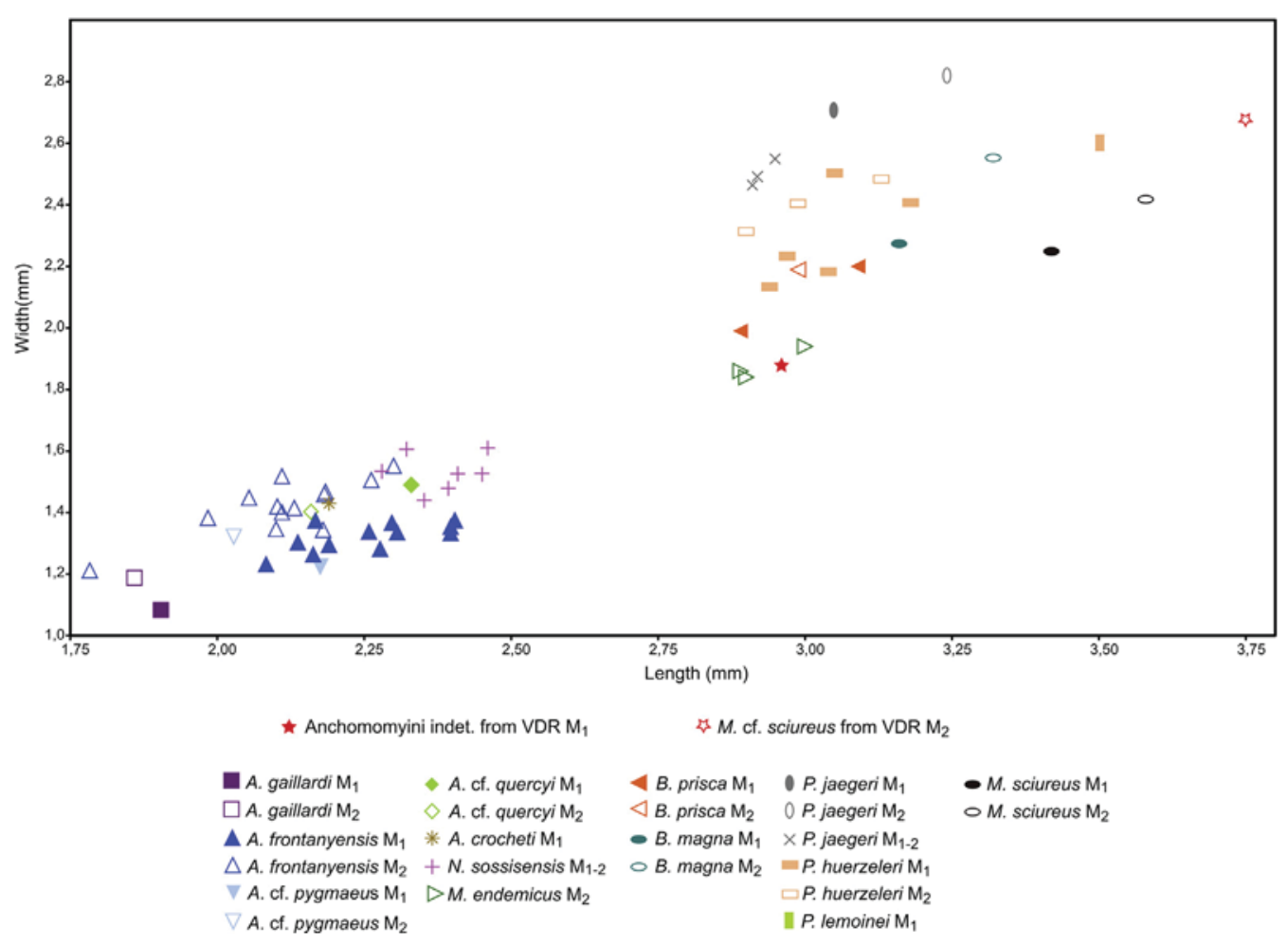

Figure 10. Size graphs (length $\times$ width) of the $\mathrm{M}_{1}, \mathrm{M}_{2}$ and $\mathrm{M}_{1-2}$ (undifferentiated) of different species of the genera Anchomomys, Buxella, Nievesia, Mazateronodon, Periconodon, Microadapis, as well as the new adapiform material from La Verrerie de Roches presented in this work. Measurements of material from VDR (Anchomomyini indet. and Microadapis cf. sciureus) have been taken directly from the original material. Data for Anchomomys frontanyensis after Marigó et al. (2011); data for other Anchomomys species taken from high quality casts and from Godinot (1988a,b); data for Nievesia sossisensis after Marigó et al. (2013); data for Mazateronodon endemicus after Marigó et al. (2010); data for Periconodon after Gingerich (1977) and Godinot (1988b); data for Buxella after Godinot (1988b); data for Microadapis after Franzen (2004). 
(Godinot, 2015), and, even though it is still included in Cercamoniinae following traditional systematic studies, its phylogenetic position remains controversial. Recent studies have presented results of phylogenetic analyses that recover anchomomyins outside of a monophyletic Adapiformes, and more closely related to azibiids, djebelemurines and extant strepsirrhines (Marigó et al., 2011, 2013, 2016; Femenias-Gual et al., 2017).

The anchomomyin from La Verrerie de Roches is morphologically very similar to $A$. frontanyensis from Sant Jaume de Frontanyà3 (Marigó et al., 2011), although much larger (Fig. 10). The genus Anchomomys was defined by Stehlin (1916) to describe the type species A. gaillardi from Lissieu (France). Later on, Godinot (1988b) revised the genus and suggested that all known species corresponded to a single lineage. However, the description of the species A. frontanyensis in the Spanish Pyrenees (Marigó et al., 2011), of the same age as A. gaillardi from Lissieu and showing clear morphological as well as size differences, suggested the existence of at least two lineages in Europe at that time, and thus a more complex phylogeny than previously hypothesized by Godinot (1988b).

Family ADAPIDAE Trouessart, 1879.

Genus MICROADAPIS Szalay, 1974.

Microadapis cf. sciureus (Stehlin, 1916)

Fig. 9D-F

\subsection{Description}

$\mathbf{M}_{2}$ : Well-preserved tooth with quite thick enamel. Subquadrate in shape, with trigonid slightly narrower than the talonid. Welldeveloped and bulbous cusps. No paraconid, but paraconid shelf present. Paracristid reaches mesiolingual base of metaconid. Metastylid present, followed by a talonid notch between metaconid and entoconid. Another talonid notch, although much smaller, is observed between the entoconid and hypoconulid. Well-developed hypoconulid. Cristid obliqua reaches base of trigonid notch between the protoconid and metaconid. Buccal cingulid present from buccal base of paraconid shelf to buccal base of hypoconulid, being interrupted at the base of the hypoconid.

\subsection{Measurements}

Length: $3.75 \mathrm{~mm}$; width: $2.68 \mathrm{~mm}$.

\subsection{Comparisons}

This tooth shows a clear adapid morphology due to the presence of a talonid notch between the metaconid and entoconid, as well as the presence of a metastylid. The only European adapid of this small size is the genus Microadapis, represented by a single species, Microadapis scriureus from Egerkingen gamma (MP13, Switzerland). The tooth from La Verrerie de Roches is very similar to the $\mathrm{M}_{2}$ of the holotype of Microadapis sciureus (NMB Eh 750) in both size and morphology, although the latter is slightly smaller (see Fig. 10). The metastylid of NMB V.R.126 is slightly more marked. We have described the tooth from VDR as an $M_{2}$ because of its asymmetrical paraconid shelf, more developed on its buccal side, as well as the presence of a metastylid, and because of the position of its cristid obliqua. The $\mathrm{M}_{1}$ of the holotype of $M$. sciureus has no metastylid, a more symmetrical and less developed paraconid shelf, and a more lingual cristid obliqua.

\subsection{Remarks on the genus Microadapis}

The genus Microadapis is represented by only the holotype of M. sciureus (NMB Eh 750). The material was originally described by
Stehlin (1916), who attributed it to the new species Adapis sciureus. Later on, Szalay (1974) separated it from Adapis and transferred the material to the new genus Microadapis. Finally, Schwartz and Tattersall (1982) transferred most of the original referred material to the new genus Simonsia, leaving M. sciureus represented by only the type material. Gebo (2002), in his revision of the Adapiformes, stated that Microadapis has non-molarized fourth premolars, although they are clearly molarized in the type specimen.

The tooth from VDR is quite similar to the $\mathrm{M}_{2}$ of $M$. sciureus. However, given the scarcity of material and the presence of some differences, we prefer not to give a definitive specific assignment to this tooth at this time.

\section{Discussion}

\subsection{On the age of La Verrerie de Roches}

The mammal assemblage from La Verrerie de Roches recently studied by Becker et al. (2013), mainly consisting of rodent remains from a single karstic fissure filling, was allocated to the Robiacian European Land Mammal Age (Middle Eocene). More specifically, this locality was assigned to the MP16 Reference Level although, according to these authors, the studied sample includes some taxa also recognized in the MP15 Reference Level (namely Elfomys tobieni). The age of the other karstic fissure fillings is unclear due to the lack of any precise provenance information. However, a similar age can be supposed for all these fissures which form a unique homogeneous karstic network, based on similar sedimentological features and bone preservation, as well as similar amphibian and reptile assemblages from these deposits (Davit Vasilyan, pers. comm.). Besides, our study of the primates from La Verrerie de Roches provides further information about the relative age of this fossil site, thanks to the presence of abundant dental remains of Necrolemur and Pseudoloris that allow detailed comparisons with the material from other well-dated localities.

The size and morphology of $N$. aff. anadoni from VDR clearly indicate an intermediate position between $N$. anadoni and $N$. antiquus. To date, $N$. anadoni has been found only in SJF-1 (type locality) and SJF-2 (some meters below), both assigned to MP15 (Minwer-Barakat et al., 2015a; Bonilla-Salomón et al., 2016). On the other hand, the oldest localities yielding remains of $N$. antiquus (Robiac, Le Bretou, Lavergne) are assigned to MP16 (Legendre et al., 1997). Therefore, the analysis of the sample of Necrolemur from VDR suggests an age between MP15 and MP16.

Regarding Pseudoloris, the species P. pyrenaicus has been identified in only the levels SJF-3C and 3D, which are slightly older than SJF-1 and 2. On the other hand, P. parvulus is a common species in fossil sites assigned to MP16 (Le Bretou) and MP17 (La Bouffie, Sossís, Perrière). Hence, the joint record of these two species in VDR is also consistent with an age between the reference levels MP15 and 16 . The species $P$. pyrenaicus and $P$. parvulus have been interpreted as ancestor and descendant respectively by Minwer-Barakat et al. (2010, 2015b). The presence of both forms in the sample from VDR may indicate a mixture of remains of different ages. This possibility cannot be ruled out; indeed, time averaging is common in faunal assemblages accumulated in karstic fissures. Moreover, the studied remains were recovered in various field campaigns, and thus it is possible that they come from diverse levels of slightly different age.

Therefore, two different hypotheses arise. In the first one (Fig. 11A), the sample from VDR would correspond to a single level with no significant time averaging. In this case, the species $P$. pyrenaicus would have coexisted with its descendant, $P$. parvulus, at least during a short time span. According to the second hypothesis (Fig. 11B), the sample from VDR would represent a 

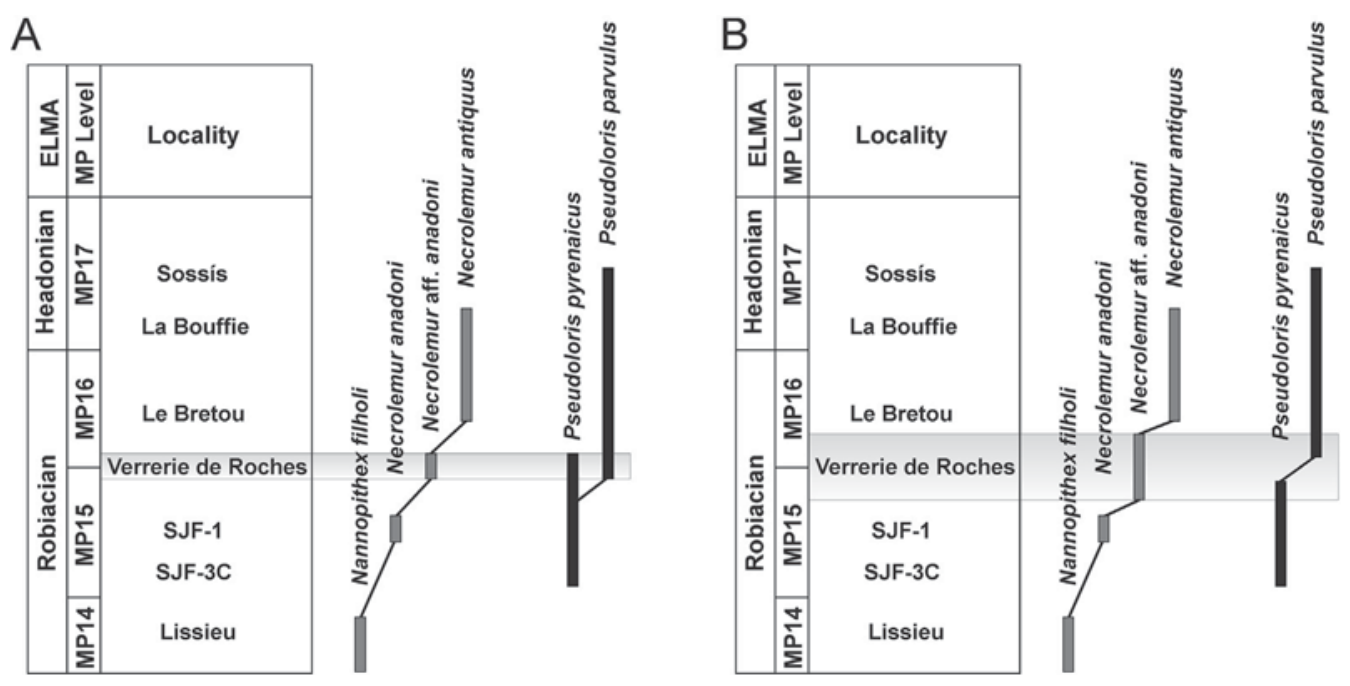

Figure 11. Stratigraphical distribution of several species of the genera Nannopithex, Necrolemur and Pseudoloris in several Middle and Late Eocene European localities, referred to the corresponding Mammal Paleogene Units (MP) and European Land Mammal Ages (ELMAs). Proposed ancestor-descendant relationships (Nannopithex filholi-Necrolemur anadoniNecrolemur aff. anadoni-Necrolemur antiquus; Pseudoloris pyrenaicus-Pseudoloris parvulus) are indicated by oblique lines. Hypothesis A: La Verrerie de Roches represents a short time span, without significant time averaging; Pseudoloris pyrenaicus coexisted with its putative descendant $P$. parvulus. Hypothesis B: La Verrerie de Roches represents a longer interval, involving some degree of temporal mixing; the joint occurrence of Pseudoloris pyrenaicus and its descendant $P$. parvulus would correspond to the mixing of faunas of different ages.

somewhat longer time interval, thus corresponding to a mixture of remains of slightly different ages. In this case, remains of $P$. pyrenaicus and $P$. parvulus would appear together as a consequence of temporal mixing, without implying the coexistence of these species. In any case, the studied sample corresponds to a relatively short and well-delimitated time interval, and can be allocated between the MP15 and MP16 reference levels, being younger than SJF-1 and older than the most ancient fossil sites yielding remains of $N$. antiquus and P. parvulus.

The description of MP15 is particularly problematic. The locality originally proposed as the MP15 reference level was La Livinière 2 (Schmidt-Kittler, 1987; Aguilar et al., 1997) but, according to Comte et al. (2012), the scarce rodent remains that were supposed to come from this fossil site most probably come from younger localities, as exogenous pollution incorporated during the processing of the samples. Indeed, all the rodent species identified in the sample from La Livinière 2 were also already recognized in Robiac (MP16), so La Livinière 2 must no longer be considered a biostratigraphic marker (Comte et al., 2012; Bonilla-Salomón et al., 2016). Other sites have been proposed as reference localities of the MP15, but no formal decision has been accepted. This is the case of Chéry-Chartreuve (Comte et al., 2012) and SJF-1 (Bonilla-Salomón et al., 2016) having yielded rodent assemblages with intermediate characteristics between older (MP14, Egerkingen, Lissieu) and younger (MP16, Robiac, Grisolles, Le Bretou) faunas. As argued by BonillaSalomón et al. (2016), the reference locality for the standard-level MP15 could be placed in some of the fossil-bearing levels from the Sant Jaume de Frontanyà section, when their faunas are fully studied.

Despite this controversy, the assignment of SJF- 1 to the MP15, as an intermediate level between MP14 and MP16, is consistent with the study of the primates found in that site (Minwer-Barakat et al., 2015a) and in the slightly older levels named SJF-3C and 3D (Minwer-Barakat et al., 2010; Marigó et al., 2011). Therefore, and pending a formal assignment of a new reference level for MP15, the primates from La Verrerie de Roches indicate a position between MP15 and MP16 reference levels, including species previously recognized in MP15 sites ( $P$. pyrenaicus), MP16 localities (P. parvulus), as well as intermediate forms ( $N$. aff. anadoni, with transitional features between $N$. anadoni from SJF-1 and $N$. antiquus from MP16 fossil sites).

\subsection{Paleobiogeographic distribution of the studied taxa}

The study of the paleobiogeographic distribution of mammals throughout the Eocene has led to the recognition of strong differences between the faunas from the central and western Iberian basins and those of Northeastern Spain and the rest of the European continent, mainly during the Middle Eocene. These differences allowed the description of the Western Iberian Bioprovince (WIB), an area including several central and western basins from Spain (Duero, Almazán, Miranda-Trebiño, Oviedo), characterized by mammals (rodents, perissodatyls and artiodactyls) significantly different from those of the Pyrenean basins and elsewhere in Europe (see Badiola et al., 2009 and references therein). The primates described from the Middle Eocene site of Mazaterón in the Almazán Basin (central Spain), unknown outside of the WIB, reinforced the endemic nature of the faunas from this province (Marigó et al., 2010; Minwer-Barakat et al., 2012). The connection of the WIB with the main European continent seems to have been reestablished by the Late Eocene, according to the presence of typical European artiodactyls (Badiola, 2004; Badiola et al., 2009) and primates (Minwer-Barakat et al., 2013b) in the Headonian (MP18) site of Zambrana in the Miranda-Trebiño Basin.

Middle Eocene primates from the Eastern Iberian Peninsula have been described from only the Sant Jaume de Frontanyà section in the Pyrenees (Minwer-Barakat et al., 2010, 2015a; Marigó et al., 2011). However, their comparison with similar-aged faunas from other European areas has been difficult due to the scarcity of fossil sites assigned to MP15. For instance, despite the extraordinary richness of fossil localities described in the Quercy phosphorites, ranging in age from the early Middle Eocene (MP11) to the Late Oligocene (MP28), none of them has been assigned to the MP15 (Legendre et al., 1997). As a result, La Verrerie de Roches deserves particular attention since it is one of the few localities of that age found in central Europe and, in addition, it contains several taxa never before identified outside the Iberian Peninsula.

Previously, P. pyrenaicus was known from only the oldest levels of the Sant Jaume de Frontanyà section (SJF-3C and 3D). The finding of this species in VDR shows that its distribution extended far from the Iberian Peninsula and included Central Europe. It is thus confirmed that the absence of this species in other European areas was due to the scarcity of localities of that age, and not to biogeographical 
reasons. The species P. parvulus, on the contrary, is well-known both in the Pyrenees (Sossís, MP17; Minwer-Barakat et al., 2015b) and northwards in France (Le Bretou, MP16; La Bouffie, Perrière, Malpérié, MP17; Godinot, 1983), England (Hordle Cliff, MP17; Cray, 1973) and Switzerland (Eclépens B, MP17; Hooker and Weidmann, 2000). The geographic distribution of these two species, forming part of the same evolutionary lineage, occupied a broad area from the Northeastern Iberian Peninsula to Central Europe and England, thus supporting the connection of the Pyrenees with the rest of the European continent during the Middle Eocene.

Similarly, $N$. anadoni was previously known from only Sant Jaume de Frontanyà. The identification of a closely related form $(N$. aff. anadoni) in La Verrerie de Roches indicates that the lineage leading from $N$. anadoni to $N$. antiquus (the latter already well known in France and Switzerland) was widespread in Central Europe, at least, in the middle Robiacian (MP15-16). Again, the absence of the earliest forms of the genus Necrolemur (N. anadoni) in Central Europe may be due to the scarcity of fossil localities corresponding to the MP15 reference level.

Summarizing, the finding in VDR of forms that were only known previously from the Pyrenees gives further support to the idea of a connection between NE Iberia and Central Europe during the Middle Eocene.

\section{Conclusions}

The Middle Eocene primate assemblage from La Verrerie de Roches (Jura, Switzerland) is described in detail. The studied material comprises more than 80 dental remains, representing five different primate taxa. The abundant remains of the microchoerine genus Necrolemur have been ascribed to $N$. aff. anadoni. This form resembles the species N. anadoni from Sant Jaume de Frontanyà (NE Spain) in size and morphology, but it also displays some features that are similar to those of $N$. antiquus, a common species in the Middle and Late Eocene of Central Europe. Moreover, the genus Pseudoloris is represented in La Verrerie de Roches by two species: the small P. parvulus and the larger P. pyrenaicus. This is the first time that these two species have been recorded in the same fossil site. Adapiformes are represented by a single tooth assigned to $M$. cf. sciureus and another tooth of an undetermined large anchomomyin.

La Verrerie de Roches was assigned to the MP16 reference level by Becker et al. (2013) on the basis of the study of a recently recovered sample, mainly consisting of rodent remains. The study of the primates from the collections housed in the NMB confirms the Robiacian age of La Verrerie de Roches. More specifically, and despite the possible temporal mixing due to the incorporation of material from different fissure fillings, we can situate La Verrerie de Roches between the MP15 and MP16 reference levels. La Verrerie de Roches represents therefore one of the oldest records of the lineage $N$. anadoni-N. antiquus, being slightly younger than the Spanish site of Sant Jaume de Frontanyà-1.

Furthermore, La Verrerie de Roches represents the first record of several primate taxa outside the Iberian Peninsula: P. pyrenaicus and a form closely related to $N$. anadoni, which were previously identified only in the Sant Jaume de Frontanyà section. The absence of these microchoerines in Central Europe previously was due to the scarcity of fossil sites assigned to MP15 rather than to any paleobiogeographical reason. The presence of these primates in Switzerland constitutes new evidence of the connection of the Northeastern Iberian Peninsula and Central Europe during the Robiacian.

\section{Acknowledgments}

We thank Burkart Engesser (NMB) for bringing the material collected in the 1970s and 1980s to our attention. We are also indebted to Marc Godinot (Muséum national d'Histoire naturelle, Paris), who provided us with casts of Necrolemur from La Bouffie that were essential for the development of this work. We thank Claude Girardin and Claudius Pirkenseer ("Paléontologie A16", "Office de la culture", Canton Jura, Switzerland) for providing access to the recent 2006 collection. We are also really grateful to the editor in chief, J. M. Plavcan, the associate editor, the copy editor, and two anonymous reviewers for their constructive comments that greatly improved the quality of the manuscript.

This study has been possible thanks to the mobility grant "International Short Visit of the SNSF", financed by the Swiss National Science Foundation (grant number IZKOZ2_154449). It is also a contribution to SNSF project 200021_162359. The Swiss Federal Roads Authority and the "Office de la culture" (Canton Jura, Switzerland) funded the 2006 excavation along the A16 motorway. This work has also been supported by the CERCA Programme/ Generalitat de Catalunya, the projects "El registro fósil de primates de la Península Ibérica durante el Cenozoico: paleobiología, biocronología y contexto paleoambiental" (CGL2014-54373-P, MINECO/FEDER, UE), Ministerio de Economía y Competitividad, Spanish Government and European Union, "Estudi dels primats i faunes associades del Paleogen de Catalunya" (2014/100604), Generalitat de Catalunya, and the research group "Grup de Recerca Consolidat Paleoprimatologia i Paleontologia Humana PIPH" (2014 SGR 416, GRC), Generalitat de Catalunya. Judit Marigó is funded by Ministerio de Economía y Competitividad, MINECO (IJCI-201526392).

\section{References}

Aguilar, J.P., Legendre, S., Michaux, J., 1997. Synthèses et tableaux de corrélations. In Aguilar, J.P., Legendre, S., Michaux, J. (Eds.), BiochroM'97: Biochronologie mammalienne du Cénozoïque en Europe et domaines reliés. Actes du Congrès BiochroM'97, École Pratique des Hautes Études Institut de Montpellier, Montpellier, pp. 769-805.

Badiola, A., 2004. Estudio paleontológico del yacimiento superior de Zambrana (Álava, Región Vasco-Cantábrica). Tafonomía, Paleobiología de Mamíferos e implicaciones Biocronológicas. Ph.D. Dissertation, Universidad del País Vasco.

Badiola, A. Checa, L., Cuesta, M.A., Quer, E., Hooker, JJ. Astibia, H., 2009. The role of new Iberian finds in understanding European Eocene mammalian paleobiogeography. Geol. Acta. 7, 243-258.

Becker, D., Rauber, G., Scherler, L., 2013. New small mammal fauna of late Middle Eocene age from a fissure filling at La Verrerie de Roches (Jura, NW Switzerland). Revue de Paléobiologie 32, 433-446.

Bonilla-Salomón, I., Minwer-Barakat, R., Vianey-Liaud, M., Moyà-Solà, S., 2016. Middle Eocene rodents from Sant Jaume de Frontanyà-1 (Eastern Pyrenees, Northern Spain) and biochronological implications. J. Vert. Paleontol. 36, e1121149.

Comte, B., Sabatier, M., Marandat, B., Vianey-Liaud, M., 2012. Les Rongeurs de Chéry-Chartreuve et Rocourt-Saint-Martin (Est du Bassin de Paris; Aisne, France). Leur place parmi les faunes de l'Éocène Moyen d'Europe. Palaeovertebrata $37,167-271$.

Covert, H.H., 2002. The earliest fossil primates and the evolution of prosimians: Introduction. In: Hartwig, W.C. (Ed.), The Primate Fossil Record. Cambridge University Press, Cambridge, pp. 13-20.

Cray, P.E., 1973. Marsupialia, Insectivora, Primates, Creodonta and Carnivora from the Headon Beds (Upper Eocene) of southern England. Bull. Br. Mus. Nat. Hist. 23, 1-102.

Crusafont-Pairó, M., 1967. Sur quelques prosimiens de l'Éocène de la Zone Préaxiale Pyrénaique et un essai provisoire de reclassification. Colloq. Internat. C.N.R.S. 163, 611-632.

Femenias-Gual, J., Minwer-Barakat, R., Marigó, J., Poyatos-Moré, M., Moyà-Solà, S. 2017. Agerinia marandati sp. nov., a new early Eocene primate from the Iberian Peninsula, sheds new light on the evolution of the genus Agerinia. PeerJ 5, e3239. http://dx.doi.org/10.7717/peerj.3239.

Franzen, J.L., 2004. First fossil primates from Eckfeld Maar, Middle Eocene (Eifel, Germany). Eclogae Geol. Helv. 97, 213-220.

Gebo, D.L., 2002. Adapiformes: Phylogeny and adaptation. In: Hartwig, W.C. (Ed.), The Primate Fossil Record. Cambridge University Press, Cambridge, pp. $21-43$.

Gingerich, P.D., 1977. New species of Eocene primates and the phylogeny of European Adapidae. Folia Primatol. 28, 60-80.

Gingerich, P.D., 2012. Primates in the Eocene. Palaeobio. Palaeoenv. 92, 649-663.

Gilbert, C.C., 2005. Dietary ecospace and the diversity of Euprimates during the Early and Middle Eocene. Am. J. Phys. Anthropol. 126, 237-249. 
Godinot, M., 1983. Contribution à l'étude des primates paleogènes d'Europe-systématique, locomotion. Ph.D. Dissertation, Université des Sciences et Techniques du Languedoc Montpellier.

Godinot, M., 1985. Evolutionary implications of morphological changes in Paleogene primates. Spec. Pap. Palaeontol. 33, 39-47.

Godinot, M., 1988a. Le gisement du Bretou (Phosphorites du Quercy, Tarn-etGaronne, France) et sa faune des vertebres de l'Eocene superieur; VI, Primates. Palaeontogr. Abt. A 205, 113-127.

Godinot, M., 1988b. Les primates adapidés de Bouxwiller (Eocène Moyen, Alsace) et leur apport à la compréhension de la faune de Messel et à l'évolution des Anchomomyini. Cour. Forsch. Inst. Senckenberg 107, 383-407.

Godinot, M., 2003. Variabilité morphologique et évolution des Necrolemur (Primates, Omomyiformes) des niveaux-repères MP 17 à MP 20 du sud de la France. Coloq. Paleontol. 1, 203-235.

Godinot, M., 2015. Fossil record of the primates from the Paleocene to the Oligocene. In: Henke, W., Tattersall, I. (Eds.), Handbook of Paleoanthropology. Springer Berlin Heidelberg, Berlin, pp. 1137-1259.

Gunnell, G.F., Rose, K.D., 2002. Tarsiiformes: evolutionary history and adaptation. In: Hartwig, W.C. (Ed.), The Primate Fossil Record. Cambridge University Press Cambridge, pp. 45-82.

Hooker, J.J., 1986. Mammals from the Bartonian (middle/late Eocene) of the Hampshire Basin, Southern England. Bull. Br. Mus. Nat. Hist., Geol. Ser. 39, 191-478.

Hooker, J.J., Harrison, D.L., 2008. A new clade of the Omomyid primates from the European Paleogene. J. Vert. Paleontol. 28, 826-840.

Hooker, J.J., Weidmann, M., 2000. The Eocene mammal faunas of Mormont, Switzerland Systematic revision and resolution of dating problems. Mém. Suisses Paléontol. 120, 1-141.

Köhler, M., Moyà-Solà, S., 1999. A finding of Oligocene primates on the European continent. Proc. Natl. Acad. Sci. 96, 14664-14667.

Legendre, S., Sigé, B., Astruc, J.G., de Bonis, L., Crochet, J.-Y., Denys, C., Godinot, M., Hartenberger, J.-L., Lévêque, F., Marandat, B., Mourer-Chauviré, C., Rage, J.-C., Remy, J.A., Sudre, J., Vianey- Liaud, M., 1997. Les Phosphorites du Quercy: 30 ans de recherche. Bilan et perspectives. Geobios Mem. Spec. 20, 331-345.

Louis, P., Sudre, J., 1975. Nouvelles données sur les primates de l'Eocène Supérieur européen. Colloq. Internat. C.N.R.S. 218, 805-828.

Marigó, J., Minwer-Barakat, R., Moyà-Solà, S., 2010. New Anchomomyini (Adapoidea, Primates) from the Mazaterón Middle Eocene locality (Almazán Basin, Soria, Spain). J. Hum. Evol. 58, 353-361.

Marigó, J., Minwer-Barakat, R., Moyà-Solà, S., 2011. New Anchomomys (Adapoidea Primates) from the Robiacian (Middle Eocene) of northeastern Spain. Taxonomic and evolutionary implications. J. Hum. Evol. 60, 665-672.

Marigó, J., Minwer-Barakat, R., Moyà-Solà, S., 2013. Nievesia sossisensis, a new anchomomyin (Adapiformes, Primates) from the early Late Eocene of the southern Pyrenees (Catalonia, Spain). J. Hum. Evol. 64, 473-485.

Marigó, J. Susanna, I., Minwer-Barakat, R., Madurell-Malapeira, J., Moyà-Solà, S., Casanovas-Vilar, I., Robles, J.M., Alba, D.M., 2014. The primate fossil record in the Iberian Peninsula. J. Iber. Geol. 40, 179-211.

Marigó, J., Roig, I., Seiffert, E.R., Moyà-Solà, S., Boyer, D.M., 2016. Astragalar and calcaneal morphology of the middle Eocene primate Anchomomys frontanyensis (Anchomomyini): implications for early primate evolution. J. Hum. Evol. 91, 122-143.

Minwer-Barakat, R., Marigó, J., Moyà-Solà, S., 2010. A new species of Pseudoloris (Omomyidae, Primates) from the Middle Eocene of Sant Jaume de Frontanyà (Eastern Pyrenees, Spain). Am. J. Phys. Anthropol. 143, 92-99.
Minwer-Barakat, R., Marigó, J., Moyà-Solà, S., 2012. Pseudoloris cuestai, a new microchoerine (Primates, Omomyidae) from the Middle Eocene of the Iberian Peninsula. J. Vert. Paleontol. 32, 407-418.

Minwer-Barakat, R., Marigó, J., Moyà-Solà, S., 2013a. Redescription and designation of a neotype for Pseudoloris reguanti Crusafont-Pairó, 1967, an Eocene primate from the Iberian Peninsula. Am. J. Phys. Anthropol. 151, 245-251.

Minwer-Barakat, R., Badiola, A., Marigó, J., Moyà-Solà, S., 2013b. First record of the genus Microchoerus (Omomyidae, Primates) in the western Iberian Peninsula and its palaeobiogeographic implications. J. Hum. Evol. 65, 313-321.

Minwer-Barakat, R., Marigó, J., Moyà-Solà, S., 2015a. Necrolemur anadoni, a new species of Microchoerinae (Omomyidae, Primates) from the Middle Eocene of Sant Jaume de Frontanya (Pyrenees, Northeastern Spain). Am. J. Phys. Anthropol. $158,730-744$

Minwer-Barakat, R., Marigó, J., Femenias-Gual, J., Moyà-Solà, S., 2015b. New material of Pseudoloris parvulus (Microchoerinae, Omomyidae, Primates) from the Late Eocene of Sossís (Northeastern Spain) and its implications for the evolution of Pseudoloris. J. Hum. Evol. 83, 74-90.

Minwer-Barakat, R., Marigó, J., Femenias-Gual, J., Costeur, L., De Esteban-Trivigno, S. Moyà-Solà, S., 2017. Microchoerus hookeri nov. sp., a new late Eocene European microchoerine (Omomyidae, Primates): New insights on the evolution of the genus Microchoerus. J. Hum. Evol. 102, 42-66.

Moyà-Solà, S., Köhler, M., 1993. Middle Bartonian locality with Anchomomys (Adapidae, Primates) in the Spanish Pyrenees: Preliminary report. Folia Primatol. 60, 158-163.

Rose, K.D., Godinot, M., Bown, T.M., 1994. 1. The early radiation of Euprimates and the initial diversification of Omomyidae. In: Fleagle, J.G., Kay, R.F. (Eds.), Anthropoid Origins. Springer Sciences + Business Media, New York, pp. 1-28.

Schmidt-Kittler, N., 1987. International symposium on mammalian biostratigraphy and paleoecology of the European Paleogene. Münchner Geowiss. Abh. 10 $1-311$.

Schwartz, J.H., Tattersall, I., 1982. Relationships of Microadapis sciureus (Stehlin, 1916), and two new primate genera from the Eocene of Switzerland. Folia Primatol. 39, 178-186.

Shackleton, N., Boersma, A., 1981. The climate of the Eocene ocean. J. Geol. Soc. London 138, 153-157.

Stehlin, H.G., 1910. Die Säugetiere des schweizerischen Eocaens. Abh. Schweiz. Paläontol. Ges. 36, 839-1164.

Stehlin, H.G., 1916. Die Säugetiere des schweizerischen Eocaens. Abh. Schweiz. Paläontol. Ges. 41, 1299-1552.

Sudre, J., 1978. Les artiodactyles de l'Eocène moyen et supérieur d'Europe occidentale; systématique et évolution. Mem. Trav. Inst. Mont. E.P.H.E. 7, 1-229.

Szalay, F.S., 1974. New genera of European Eocene adapid primates. Folia Primatol. 22, 116-133.

Thalmann, U., 1994. Die Primaten aus dem eozänen Geiseltal bei Halle/Saale (Deutschland). Cour. Forsch. Inst. Senckenberg 175, 1-142.

Trouessart, E.L., 1879. Catalogue des mammifères vivants et fossiles. Rev. Mag. Zoo. 7, 223-230

Vandenberghe, N., Hilgen, F.J., Speijer, R.P., 2012. The Paleogene Period. In: Gradstein, F.M., Ogg, J.G., Schmitz, M.D., Ogg, G.M. (Eds.), The Geologic Time Scale 2012. Elsevier, Oxford, pp. 855-921.

Zachos, J., Pagani, M., Sloan, L., Thomas, E., Billups, K., 2001. Trends, rhythms, and aberrations in global climate 65 Ma to Present. Science 292, 686-693.

Zachos, J.C., Dickens, G.R., Zeebe, R.E., 2008. An early Cenozoic perspective on greenhouse warming and carbon-cycle dynamics. Nature 451, 279-283. 